\title{
ANALISIS COST VOLUME PROFIT SEBAGAI ALAT PERENCANAAN LABA (STUDI KASUS PADA UMKM DENDENG SAPI DI BANDA ACEH)
}

\author{
Alvini Hassanah*1, Rulfah M. Daud ${ }^{* 2}$ \\ ${ }^{1,2}$ Program Studi Akuntansi Fakultas Ekonomi dan Bisnis Universitas Syiah Kuala \\ e-mail: alvinihassanah6@gmail.com ${ }^{* 1}$,rulfahm.daud@ unsyiah.ac.id $^{* 2}$
}

\begin{abstract}
Abstrak
A company needs planning to assist management in assessing the level of profit to be gained, with a Cost Volume Profit analysis that focuses on the various factors that affect changes in the components of profit. This study aims to determine the application of CVP analysis as the basis of profit planning is expected 2018. The metodh used is descriptive method with empirical study approach. Researcher collets company information then do data analysis. CVP analysis is done by break even point (BEP), contribution margin (CM), margin of savety (MOS), operating laverage (OL). The result showed by Gunung Seulawah that in 2017 the contribution margin was Rp. 2.833.357.000,00,-, minimum sales of 38.366 units or $R p$. 9.207.736.265,- , break even point $R p$ 872.263.735,00,with a total of as many as 3,634 units and operating laverage 1,09. The result showed by Bungong Jaroe that in 2017 the contribution margin was Rp. 1.102.573.000,,00,-, minimum sales of 15.020 units or Rp. 3.304.403.000,00-, break even point $R p$. 655.596.999,00- with a total of as many as 2.980 units and operating laverage 1,20. The result showed by Rencong Aceh that in 2017 the contribution margin was 95.580.300,.00,00,-, minimum sales of 713 units or Rp. 171.179.274,00-, break even point Rp. 116,820,726,00- with a total of as many as 487 units and operating laverage 1,68. The companies set a profit of $15 \%$ over the previous year. To achieve expected profit, sales are targeted at Rp. 2.976.401.250,00- for Gunung Seulawah Rp. 1.058.042.263,00.- Bungong Jaroe and Rp. 65.331.845,00,- Rencong Aceh. Mangement can apply CVP analysis to assist in planning earnings in the coming year.
\end{abstract}

Keywords: Cost Volume Profit, Perencanaan Laba, Break Even Point, UMKM.

\section{Pendahuluan}

\section{Latar Belakang}

Peningkatan pertumbuhan usaha kecil di Indonesia mengalami kenaikan setiap tahunnya, dapat dilihat melalui data yang diperoleh dari Kementrian Koperasi dan Usaha Kecil Menengah pada periode 2011-2013, persentase jumlah usaha kecil mengalami kenaikan sebesar 2,41\% setiap tahunnya (www.depkop.go.id). Begitu pula data UMKM yang diperoleh dari Dinas Koperasi Usaha Kecil Menengah Aceh pada tahun 2016 terdapat 71\% jumlah unit usaha mikro, $27 \%$ jumlah unit usaha kecil dan $2 \%$ jumlah unit usaha menengah (www.diskop.acehprov.go.id).

Terlihat bahwa UMKM juga sesuatu yang di anggap penting bagi Pemerintah Indonesia yang dapat kita lihat dari Undang-Undang Republik Indonesia Nomor 20 Tahun 2008 mengenai Usaha Mikro, Kecil dan Menengah (UMKM). UKM juga salah satu bentuk perusahaan manufaktur yang mempunya peranan penting dalam pertumbuhan perekonomian masyarkat (UUD RI Nomor 20 tahun 2008). UMKM pada bidang industri yang juga masuk kedalam salah satu jenis perusahaan manufaktur.

Perusahaan-perusahaan manufaktur baik yang berskala kecil maupun skala besar pasti dalam aktivitas usahanya berorientasi untuk mencapai tujuan perusahaan seperti memaksimalkan perolehan laba, memepertahankan kehidupan perusahaan, menghasilkan pertumbuhan perusahaan kearah yang lebih baik serta menciptakan kesejahteraan anggota internal maupun eksternal perusahaan. keputusan yang berkenaan dengan tujuan utama di dalam perusahaan adalah memaksimalkan perolehan laba, sehingga untuk memperoleh laba yang maksimal perusahaan harus dapat menargetkan berapa laba yang akan dicapai serta perusahaan juga harus memikirkan bagaimana cara untuk mencapai laba 
yang diharapkan dengan semaksimal mungkin. Manajer harus dapat membuat sebuah perencaan yang baik agar dapat memanfaatkan sumber daya yang diatur secara terorganisir dan terkendali.

Perencanaan yang merupakan salah satu bentuk dari fungsi manajemen merupakan kegiatan yang dibuat untuk memberikan feed foorward (umpan maju) agar dapat memberikan petunjuk kepada manajer saat pengambilan keputusan (Kembi, Sondakh, \& Tirayoh, 2014). Menurut Iswara \& Susanti (2017) manajer dapat menggunakan langkahlangkah berikut untuk mencapai laba yang optimal: 1) menekan biaya operasional serendah mungkin dengan mempertahankan tingkat harga dan volume penjualan, 2) menentukan tingkat harga jual sedemikan rupa sesuai dengan laba yang dikehendaki, dan 3) meningkatkan volume penjualan sebesar mungkin. Sebuah perkiraan tingkat laba yang akan dicapai oleh perusahaan memiliki kaitan yang erat dengan sebuah perencanaan laba yang baik.

Pencapaian strategi yang benar di dalam perencanaan laba pada perusahaan yang sudah jelas berkenaan tentang laba ternyata dipengaruhi oleh 3 faktor yaitu volume produksi, harga jual, dan biaya Volume, laba dan biaya harus dapat dikelola dengan baik agar dapat diperoleh formula yang tepat dalam pencapaian laba yang maksimal (Winarko et al., 2017). Analisis yang cukup tepat untuk memahami hubungan timbal balik antara biaya, volume, dan laba adalah analisis CVP (cost volume profit). Analisis CVP perusahaan akan memepunyai sebuah gambaran yang akan dijadikan sebagai pedoman dalam keputusan yang dipilih mengenai berapa besarnya penjualan minimal yang harus dipertahankan agar perusahaann tidak mengalami kerugian, menghasilkan perencanaan jumlah penjualan yang harus dicapai untuk mendapatkan laba yang diharapkan.

Sehingga hubungan antara analisis CVP dalam sebuah perencanaan laba dapat digunakan menggunakan beberapa alat yaitu menghitung BEP (break even point/titik impas), MOS (margin of safety), CM (contribution margin), struktur biaya atau OL (Operating Laverage. Analisis CVP juga dapat digunakan pada UMKM, penulis berniat melakukan penelitian menggunakan salah satu alat manajemen ini pada salah satu jenis UMKM yang ada di Banda Aceh yang bergerak pada pembuatan dendeng sapi yang masuk kedalam UMKM bidang industri.

Analisis CVP juga dapat digunakan pada UMKM, penulis berniat melakukan penelitian menggunakan salah satu alat manajemen ini pada salah satu jenis UMKM yang ada di Banda Aceh yang bergerak pada pembuatan dendeng sapi yang masuk kedalam UMKM bidang industri. Alasan yang menjadikan UMKM Dendeng Sapi layak dilakukan penelitian karena UMKM Dendeng Sapi di Banda Aceh merupakan UMKM yang menghasilkan salah satu ikon buah tangan yang memiliki cita rasa kahs pada bumbunya yang berasal dari Aceh. Namun jumlah UMKM yang berjumlah sedikit berlawanan dengan permintaan pasar yang tinggi menjadi sesuatu yang disayangkan apabila UMKM Dendeng Sapi belum bisa memenuhi permintaan konsumen dikarenakan rendahnya produktivitas.

Permasalahan ini yang membuat penulis teratrik dalam menggunakan analisis CVP terhadap UMKM Dendeng Sapi sebagai sarana untuk dilakukan penelitian. Penulis memperkirakan alasan lain yang mempengaruhi kurangnya minat masyarakat pada UMKM dendeng dikarenakan mahalnya harga daging di Banda Aceh yang dijadikan sebagai bahan baku utama dalam pembuatan dendeng yang berpengaruh terhadap harga dendeng yang mahal. Terdapat 3 UMKM Dendeng Sapi yang akan diteliti masing-masing UMKM memiliki harga yang berbeda serta haraga bahan pokok yaitu daging sapi yang berbeda pula.

Pada penelitian ini, peneliti akan menggunakan analisis CVP untuk membantu 3 UMKM Dendeng Sapi dalam pembuatan perencanaan laba yang diaharapkan, peneliti akan mencoba melihat faktor-faktor yang dapat memengaruhi biaya-biaya, volume penjualan serta laba pada masing-masing UMKM Dendeng Sapi. Dari fenomena tersebut penulis tertarik untuk dapat melakukan sebuah penelitian dengan judul "Analisis CVP (Cost Volume Profit) Sebagai Perencanaan Laba (Studi Kasus Pada UMKM Pembuatan Dendeng Aceh Di Kota Banda Aceh)".

\section{Rumusan Masalah}

Rumusan masalah dalam penelitian ini berdasarkan latar belakang adalah: 
1. Berapa besarnya laba yang direncanakan pada UMKM pembuatan dendeng sapi di Banda Aceh ?

2. Berapa tingkat penjualan yang dihasilkan agar dapat memenuhi target laba yang ingin dicapai oleh UMKM

3. pembuatan dendeng sapi di Banda Aceh?

4. Berapa besarnya BEP atau titik impas pada UMKM pembuatan dendeng sapi di Banda Aceh?

5. Berapa besarnya MOS pada UMKM pembuatan dendeng sapi di Banda Aceh?

6. Berapa besarnya OL UMKM pembuatan dendeng sapi Banda Aceh?

\section{Tujuan Penelitian}

Berdasarkan rumusan masalah, maka yang menjadi tujuan penelitian ini adalah untuk mengetahui:

1) Mengetahui besarnya laba yang direncanakan UMKM pembuatan dendeng sapi yang ada di Banda Aceh.

2) Mengetahui tingkat penjualan yang direncanakan untuk mencapai laba yang ditergetkan oleh UMKM pembuatan dendeng sapi di Banda Aceh.

3) Untuk menentukan nilai (BEP) pada UMKM pembuatan dendeng sapi di Banda Aceh.

4) Untuk menentukan nilai MOS pada UMKM pembuatan dendeng sapi di Banda Aceh.

5) Untuk menentukan nilai OL pada UMKM pembuatan dendeng sapi di Banda Aceh.

\section{Kajian pustaka}

\section{Biaya}

Biaya merupakan pengorbanan yang dibuat, biasanya diukur dengan sumber daya yang diberikan, untuk mencapai tujuan tertentu (Hilton, Maher, \& Selto, 2003:37). Terdapat Klasifikasi biaya menurut Needles \& Crosson (2011:47) dapat digolongkan sebagai berikut:

1) Cost Traceability

2) Cost Behavior

3) Value-Adding Attributes

4) Financial Reporting

dari beberapa klasifikasi yang telah dipaparkan maka klasifikasi golongan biaya yang diperlukan dalam melakukan analisis CVP merupakan cost behavior atau prilaku biaya, karena cost behavior merupakan biaya yang berhubungan dalam perubahan volume kegiatan didalam perusahaan yang pasti mempengaruhi laba yang akan dicapai perusahaan. Perilaku biaya menunjukan reaksi dari biaya terhadap aktivitas perusahaan, jika aktivitas bertambah atau berkurang maka biaya tertentu akan naik maupun turun bisa juga, tetap (Garisson, Noreen dan Brewer 2014:30). Cost Behavior terdiri dari Biaya tetap (fixed cost), Biaya variabel (variabel cost), Biaya Semi Variabel.

\section{Volume Penjualan}

Volume penjualan biasanya diartikan secara umum adalah jumlah penjualan. Menurut Mulyadi (2001:239) volume penjualan adalah ukuran yang menunjukan besarnya ataupun jumlah terjualnya barang dan jasa. Volume penjualan juga mempengaruhi laba yang ada di dalam perusahaan, karena jika volume penjualan diperusahaan mengalami kenaikan maka semakin besar peluang perusahaan mendapatkan labanya begitu juga sebaliknnya laba yang kecil juga biasanya dipengaruhi dari kecilnya volume penjualan di suatu perusahaan. Pada intinya volume penjualan sangat mempengaruhi laba karena volume penjualan sendiri bisa disebut sebagai alat untuk mengevaluasi keadaan perusahaan.

\section{Laba dan Perencanaan Laba}

Laba merupakan selisih antara total penghasilan dan total biaya yang dikeluarkan pada suatu kegiatan usaha. Sehingga laba dalam analisis CVP merupakan total penjualan dikurangi oleh total biaya. Perencanaan merupakan apa yang akan dilakukan oleh sebuah manajemen pada periode di masa yang akan datang dan dalam waktu tertentu (Machfoeds, 2000). Perencanaan laba adalah salah satu bentuk sebuah perencanaan yang paling penting yang ada didalam sebuah perusahaan, perencaaan laba dianggap penting karena perencanaan laba dapat dijadikan sebuah alat tolak ukur kinerja perusahaan demi kebelangsungan hidup perusahaan (Iswara \& Susanti, 2017).

Hal yang terpenting dalam perencanaan atau tujuan utama didalam perusahaan sudah pasti mencapai laba semaksimal mungkin sehingga 
penggunaan perencanaan laba dalam perusahaan bertujuan terhadap penetapan target laba yang akan dicapai. Target laba akan menggambarkan tingkat volume penjualan dan biaya yang harus dianggarkan perusahaan untuk dapat mencapai laba yang diharapkan untuk periode yang direncanakan.

Pembuatan perencanaan manajemen harus tetap bisa memaksimalkan manfaat dari pembuatan perencanaan di dalam manajemen, salah satu langkah yang baik adalah menggunakan analisis CVP dan analisis BEP dalam pembuatan perhitungan perencanaan laba agar mnghasilkan perencanaan yang jelas serta akurat.

\section{Analisis Cost Volume Profit (CVP)}

Analisis CVP merupakan sebuah teknik dalam meneliti perubahan terhadap keuntungan yang berpengaruh kepada volume penjualan, biaya dan harga (Eldenburg, et, al., 2011:124). Analisis CVP juga suatu alat yang sangat berguna dalam perencanaan dan pengambilan keputusan, mengapa dikatakan begitu karena analisis CVP sangat menekankan keterkaitan antara biaya, kuantitas yang terjual, harga jual dan semua informasi keuangan yang ada didalam perusahaan (Hansen \& Mowen, 2009:4). CPV dapat didasarkan pada data historis maupun data proyeksi, namun CPV tidak dapat kita ambil langsung dari laporan laba rugi yang dibuat berdasarkan perhitungan biaya seluruhnya karena dapat dampak setiap adanya aktivitas terhadap biaya tidak dapat ditentukan secara langsung. Perusahaan dapat menggunakan analisis CPV untuk menetapkan tujuan penjualan, untuk menganalisis apakah proyek potensial cenderung menguntungkan dan untuk melihat potensi keuntungan yang maksimal atau kerugian dari proyek tertentu, serta mana titik impas yang tidak tepat (Punniyamoorthy, 2017).

CPV membuat manajer harus bisa mengatur target laba yang diinginkan dan fokus terhadap sesuatu yang berhubungan untuk mencapainya seperti nilai laporan laba rugi yang diketahui untuk menemukan sesuatu yang belum diketahui, maksud dari sesuatu yang belum diketahui adalah volume penjulan yang dibutuhkan dalam pencapaian target laba tertentu. Dasar asumsi CPV adalah pemisahan semua biaya menjadi biaya tetap dan biaya variabel, dan total biaya tetap adalah konstan sedangkan total biaya variabel berubah secara proporsional terhadap perubahan volume.

Biaya menentukan harga jual untuk sampai pada tingkat yang diinginkan keuntungan. Harga jual mempengaruhi volume penjualan, volume penjualan langsung mempengaruhi volume produksi dan volume produksi pada gilirannya mempengaruhi biaya ini merupakan faktor yang paling mendasar yang di bahas oleh analisis CPV (Navaneetha, Punitha, Joseph, Rashmi\& Aishwariyaa, 2017).

\section{Analisis Break Even Point / Titik Impas (BEP)}

Saat suatu perusahaan memiliki keinginantahuan mengenai pendapatan, beban dan laba yang berpengaruh ketika volume penjualan berubah dapat dimulai dari penentuan titik impas perusahaan dalam jumah unit produk yang dijualnya. Titik impas menurut Hansen dan Mowen (2009:4) merupakan titik dimana total pendapatan yag diterima sama dengan total biaya yang dikeluarkan, dimana laba perusahaan sama dengan nol. Perusaahaan yang mengalami BEP sudah pasti tidak dalam keadaan rugi atau mendapatkan keuntungan.

BEP akan membantu manajer dalam mengatur tujuan penjualan yang dapat menghasilkan laba yang diharapkan dari operasi yang berlangsung. Dalam penentuan BEP manajer harus memiliki pemahaman mengenai pendapatan dan biaya yang dikeluarkan perusahaan. BEP dapat disimpulkan bahwa dimana keadaan perusahaan tidak dalam kerugian atau keuntungan yaitu biaya yang sudah dikeluarkan perusahaan sama besarnya dengan pendapatan yang diterimanya. BEP dapat dihitung dengan menggunakan persamaan atau menggunakan metode margin kontribusi.

1) Metode persamaan (equation metodh) dalam penghitungan BEP

Titik impas dalam penjualan (Rp)

\section{Pendapatan- Biaya Variabel-Biaya Tetap = Laba Operasi \\ Penjualan = Biaya Variabel + Biaya Tetap $+L a b a$ Operasi}
2) Metode Margin Kontribusi
Titik impas dalam penjualan (Rp) 


\section{BEP $($ Rp $)=$ Biaya Tetap / Rasio Margin Konrtribusi \\ Rasio Kontribusi Margin = Contribusi Margin / Penjualan}

Titik impas dalam unit penjualan (unit)

\section{Bep $($ Unit $)=$ Biaya Tetap / Margin Kontrubusi Per Unit}

\section{Contribution Margin}

$\mathrm{CM}$ adalah kelebihan pendapatan penjualan di atas biaya variabel. CM adalah jumlah yang tersisa dari pendapatan penjualan dikurangi dengan beban variabel (Garrison et all,2014:209).

Rumus yang digunakan dalam menghitung CM margin rasio merupakan perbandingan $\mathrm{CM}$ dengan total penjualan (Winarko et al., 2017). Contribution margin rasio mengidentifikasi jumlah kenaikan atau penurunan laba yang disebabkan kenaikan atau penurunan penjualan tertentu dalam Rupiah. Menurut Winarko et al., (2017) dan Murthosiyah et al., (2015) contribution margin rasio dapat dihitung menggunakan :

\section{Margin Kontribusi = Penjualan - Biaya Variabel}

\section{$C M$ Rasio $=$ Total CM $/$ Total Penjualan}

CM yang rendah akan mengakibatkan BEP yang tinggi sedangkan $\mathrm{CM}$ yang tinggi akan mengakibatkan BEP yang rendah. Tinggi rendahnya BEP yang dicapaiakan berpengaruh pada laba yang diterima oleh perusahaan yaitu sampai padatingkat batas keselamatan.

\section{Margin of safety}

MOS merupakan jumlah penjualan yang direncanakan di atas titik impas (Blocher et al,2011:525). Kelebihan dari penjualan dalam dollar yang telah dianggarakan di atas titik impas nilai penjualan dalam dalam rupiah adalah MOS menurut Garrison et al., (2014:225).

Hasil perhitungan titik keamanan menunjukkan jumlah sampai seberapa besar penjualan dapat turun sehingga sampai pada titik impas. MOS yang memiliki nilai yang tinggi akan menunjukan rendahnya resiko perusahaan untuk tidak mencapai titik impas. Perhitungannya dapat dinyatakan dalam unit, satuan uang, dan persentase. MOS yang besar menunjukkan bahwa kondisi perusahaan tidak dalam bahaya, dan sebaliknya jika MOS kecil mendekati nol persen menunjukkan bahwa perusahaan dalam kondisi bahaya yaitu akan mengalami titik impas. Jika MOS negatif berarti perusahaan dalam kondisi bahaya, yaitu mengalami kerugian. Menghitung MOS :

MOS = penjualan aktual - BEP

MOS (\%) $=$ MOS / total penjualan yang dianggarkan (actual)

MOS dapat juga dinyatakan dalam rupiah atau dalam bentuk persentase. Persentase ini dicari dengan membagi margin pengamanan penjualan dengan jumlah rupiah penjualan, seperti dalam rumus berikut :

\section{$\operatorname{MOS}(\mathrm{Rp})=\operatorname{MOS}(\mathrm{Rp}) / \mathrm{TOTAL}$ penjualan actual ( di anggarkan $) * 100 \%$ \\ to}

Biaya tetap yang digunakan untuk mengurangi biaya variabel dengan sedemikian rupa akan berdampak pada peningkatan CM dan penurunan laba, maka tingkat OL naik yang menunjukan bahwa adanya peningkatan risiko.

\section{OL (Operating Leverage)}

OL adalah sebuah alat pengukur tentang sensitivitas laba bersih operasi terhadap penjualan dalam bentuk dollar (Garisson et al, 2014:228). Biaya tetap yang digunakan untuk mengurangi biaya variabel dengan sedemikian rupa akan berdampak pada peningkatan $\mathrm{CM}$ dan penurunan laba, maka pada tingkat OL naik akan menunjukan bahwa adanya peningkatan risiko. Menurut Blocher (2011) setiap perusahaan juga biasanya memiliki OL yang konsisten dengan strategi dalam persaingannya beda halnya dengan pendapat Garissson (2014) menurutnya tingkat OL tidak konstan maka tingkat tertinggi akan dicapai pada penjualan yang mendekati titik impas dan menurunkan ketika penjualan dan laba meningkat. Dapat dihitung dengan rumus ;

Degree of operating = Contribution Margin $/$ Laba 
Biaya tetap yang digunakan untuk mengurangi biaya variabel dengan sedemikian rupa akan berdampak pada peningkatan CM dan penurunan laba, maka pada tingkat OL naik akan menunjukan bahwa adanya peningkatan risiko. Menurut Blocher (2011) setiap perusahaan juga biasanya memiliki OL yang konsisten dengan strategi dalam persaingannya beda halnya dengan pendapat Garissson (2014) menurutnya tingkat OL tidak konstan maka tingkat tertinggi akan dicapai pada penjualan yang mendekati titik impas dan menurunkan ketika penjualan dan laba meningkat.

\section{Metode Penelitian \\ Desain Penelitian}

Tujuan peneitian ini bersifat deskriptif, penelitian ini memaparkan kondisi objek penelitian berdasarkan pada keadaaan sebenarnya yang ada di lapangan. Tujuan utama dalam penelitian ini untuk melakukan analisis CPV dalam melakukan perencanaan laba di periode yang akan datang pada UMKM industri makanan dendeng sapi yang ada di Kota Banda Aceh dengan menggunakan BEP, CM, MOS OL. Jenis investigasi dalam penelitian ini adalah koresional, dimana peneliti hanya akan mengidentifikasi hal-hal yang berkaitan terhadap studi yang akan dilakukan. Pada jenis investigasi ini yang akan diidentifikasi dalam penelitian merupakan biayabiaya yang dikeluarkan dalam proses produksi pada pembuatan dendeng sapi, volume penjualan yang dicapai setiap UMKM setiap periodenya, dan laba yang dicapai perusahaan dalam pembuatan perencanaan laba periode yang akan datang pada setiap UMKM pembuatan dendeng sapi di Banda Aceh.

Dalam penelitian ini tingkat interversi peneliti merupakan tingkat interversi minimal. Situasi penelitian yang dilaksanakan oleh peneliti menggunakan situasi yang di atur. Peneliti mengambil unit analisisnya dalam tingkatan beberapa unit usaha dendeng sapi yang ada di Banda Aceh. Horizon waktu yang digunakan dalam penelitian ini adalah cross sectional.

\section{Populasi dan Sampel}

Populasi mengacu pada sekelompok orang, peristiwa, atau hal-hal menarik yang ingin diteliti (Sekaran dan Bogie, 2016:177). Populasi dalam penelitian ini adalah Usaha Kecil dan Menengah manufaktur makanan Dendeng Sapi di Banda Aceh yang terdaftar didalam data tahunan Badan Pusat Statistik Aceh pada tahun 2017.

Sampel adalah bagian dari populasi yang akan diteliti. Sampel terdiri dari beberapa anggota yang dipilih dari populasi (Sekaran \& Bogie, 2013:241). Pengambilan sampel dalam penelitian ini menggunakan teknik pourposive sampling, karena kriteria disusuaikan dengan syarat yang dibutuhkan oleh penelitian yang dilakukan. Sampel yang dipilih akan mewakili hasil dari penelitian terhadap populasi yang dilakukan oleh peneliti. Pengambilan Sampel dalam penelitian ini adalah sebagai berikut:

1) UMKM Dendeng Sapi yang terdata dalam pendataan BPS tahun 2017.

2) UMKM yang memang melakukan produksi dan penjualan.

3) UMKM Dendeng Sapi yang memiliki kriteria kecil.

4) UMKM Dendeng Sapi yang masih aktif berproduksi.

Terdapat 3 unit usaha dendeng sapi yang ada di banda aceh yang memenuhi syarat sebagai sampel yang sesuai dengan kriteria yang telah ditentukan dalam penelitian ini

\section{Sumber Data Dan Tehnik Pengumpulan Data}

Sumber data pada penelitian ini adalah data primer dan data sekunder. Data primer merupakan laporan penelitian dalam jurnal ilmiah atau berkala dimana penulis menggambarkan penelitian berdasarkan sudut pandangnya termasuk alasan penulis melakukan penelitian tersebut, bagaimana penelitian dilakukan, hasil apa yang ditemukan dan bagaimana hasil tersebut ditafsirkan. Data primer diperoleh melalui wawancara kepada setiap pemilik usaha dendeng sapi yang akan diteliti.

\section{Metode Analisis}

Metode analisis data yang digunakan alam penelitian ini adalah metode deskriptif dimana dengan pendekatan studi kasus. Proses dalam menganalisis data sebagai berikut:

1) Mengumpulkan dokumen atau data-data yang diperlukan yang ada di unit usaha dendeng sapi di Banda. 
2) Mengklarifikasikan semua biaya-biaya yang dikeluarkan unit usaha dendeng sapi ke dalam biaya variabel dan biaya tetap.

4. 3) Melakukan analisis analisis BEP yang bertujuan untuk mengetahui tiitk impas dimana perusahaan tidak mengalami kuntungan maupun kerugian.

\section{Hasil dan Pembahasan}

\section{Gambaran Umum Industry Dendeng Sapi Di Banda Aceh \\ Sejarah UMKM Dendeng Sapi}

UMKM penjualan dendeng sapi merupakan salah satu UMKM yang bergerak di industti makanan yang ada di kota Banda Aceh. UMKM Dendeng Rencong Aceh merupakan suatu industri rumah tangga yang berdiri pada tahun 2000. Industri dendeng Rencong Aceh ini beralamat di Jalan Hají Zakaria, Lamsuepeung, kecamatan Lueng Bata Banda Aceh. Nama pemilik Industri ini adalah Bapak Husen, yang modal awal usahanya berasal dari pribadi Bapak Said Husen sendiri. Dalam, kegiatan industrinya UMKM Rencong Aceh mampu memproduksi \pm 130 daging sapi menrah yang diolah menjadi $\pm 100 \mathrm{~kg}$ perbualannya untuk dilakukan penjualan dimana setiap produknya di bandrol seharga Rp. 240.000,- per kilogramnya.

Bapak Husein membangun usaha dendeng dengan istrinya yang bernama Siti Aminah yang bermodalkan \pm Rp. 200.000.- dan dibekali dengan pengalaman pernah bekerja di salah satu usaha dendeng sapi di Seulawah. Dari modal yang dimiliki bapak Husein dan ibu Siti Aminah usaha dendeng tersebut dapat berkembang hingga pada tahun 2003 bapak Husein dan Aminah pun mulai membuat kotak sebagai kemasan dendengnya, setelah sebelumnya hanya dibalut dengan kertas seadanya. Mulai dari cara pemasarannya yang sudah mulai berkembang, yang pada awalnya hanya sebatas menitipkan di warungwarung nasi, mereka juga menitipkan dendeng di beberapa toko souvenir yang ada di Banda Aceh. UMKM dendeng Rencong Aceh memiliki 3 orang karyawan yang terdiri dari 3 orang pekerja.

UMKM dendeng sapi selanjutnya adalah UMKM dendeng Bungong Jaroe yang dibangun pada tahun 2006. Bungong Jaroe berlokasi di di Jalan Teuku Umar No.149 Setui, Banda Aceh. Pemilik dari UMKM Bungong Jaroe bernama Mahdi Usman, tempat untuk melakukan kegiatan produksi tidak jauh dari lokasi toko masih di daerah Setui tepatnya di rumah mertua bapak Mahdi Usman.

Produk dendeng bungong jaroe juga dipasarkan di swalayan-swalayan serta toko-toko souvenir dan juga dijual sendiri di toko yang dimiliki oleh Bapak Usman. Jumlah Pegawai yang ada di UMKM dengdeng Bungong Jaroe terdapat 7 orang untuk produksi, 2 orang untuk penjaga toko dan 5 orang tambahan untuk membantu penjemuran daging sapi.

UMKM yang ketiga memiliki merek produk dagang Gunung Seulawah, Dendeng Gunung Seulawah telah dirintis sejak tahun 1978 oleh Bapak H. Lukman Hakim. Dendeng Gunung Seulawah adalah prodok lokal dendeng yang ada di Banda Aceh, Lokasi usaha ada di Jalan Teungku Chik di Tiro Simpang Surabaya Banda Aceh.

\section{Struktur Organisasi}

Struktur organisansi pada UMKM dendeng masih tergolong sederhana, berdsarkan dari proses produksi dendeng dalam penelitian ini, maka dapat disimpulkan bahwa setiap umkm memiliki kesamaan struktur organisasi seperti berikut. UMKM Dendeng Rencong Aceh memiliki 3 orang karyawan yang terdiri dari istri dan sanak saudaranya. Bapak Said Husein sendiri juga turut ikut serta membantu dalam proses pembuatan dendeng.

UMKM Dendeng Bungong Jaroe memiliki 14 karyawan yang terdiri dari 7 orang karyawan pada bagian produksi, 5 orang karyawan tambahan yang membantu dalam proses penjemuran daging serta 2 orang karyawan yang bekerja di toko. Umkm dendeng Gunung Seulawah terdiri dari 14 orang karyawan yang terdiri dari 9 oroang karyawan pada bagian produksi, dan sisanya bekerja di toko. 


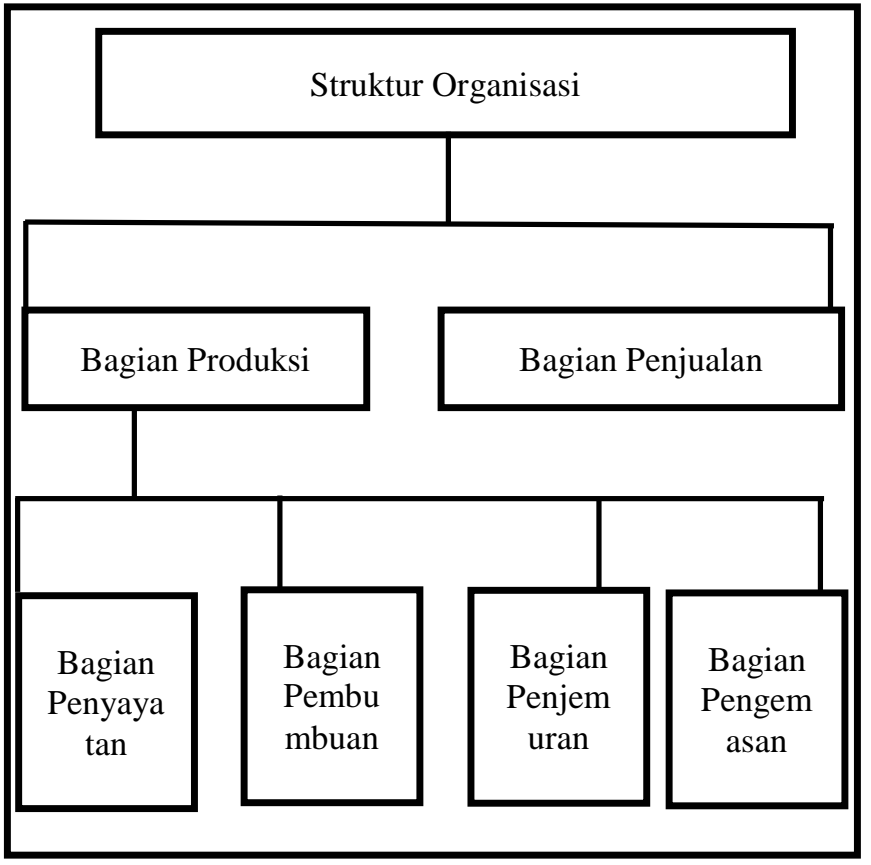

Gambar 4.1 Struktur Organisasi Industri UMKM Dendeng Sapi

\subsection{Proses Pembuatan Dendeng Sapi}

Dalam proses pembuatan dendeng sapi, bahan baku yang digunakan adalah Daging Sapi, ketumbar, gula, dan bawang putih ketiga UMKM dendeng sapi sama-sama menggunakan empat bahan baku tersebut, tetapi UMKM dendeng bungong jaroe memiliki satu bahan baku yang ditambahkan dalam komposisi pembuatan dendeng yaitu serai, begitu juga pada UMKM rencog aceh juga menambah garam dalam proses pembuatan dendengnya. Terdapat beberapa tahapan yang dilakukan dalam memproduksi dendeng sapi seperti dalam tabel berikut:

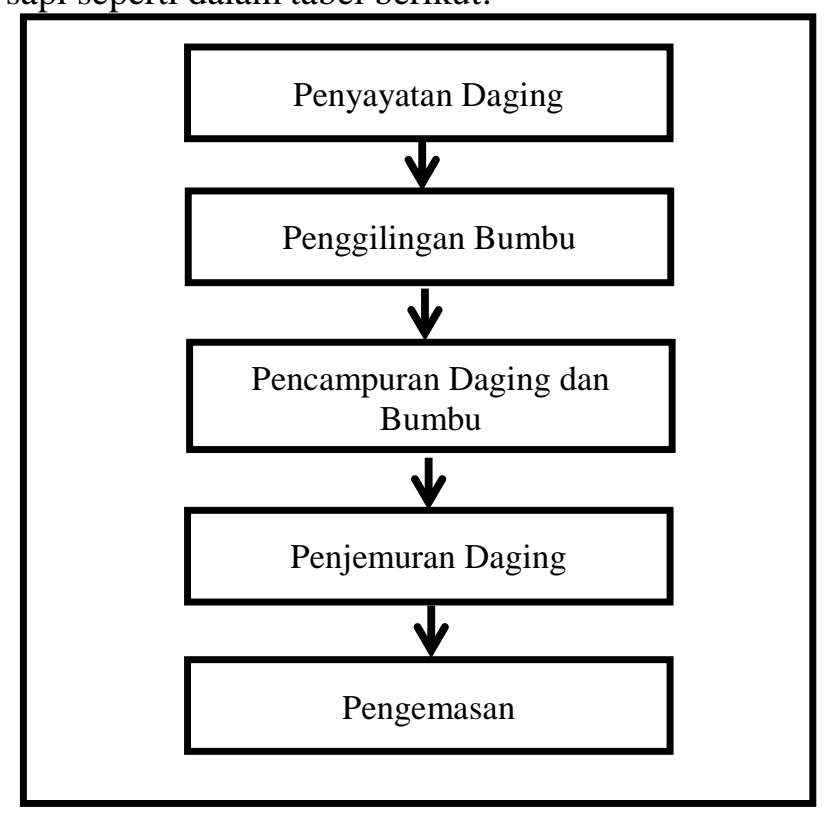

Gambar 4.2 Proses Pembuatan Dendeng Sapi

\section{Penyajian Data Penelitian}

Data yang digunakan dalam penelitian adalah data primer yang di dapat melalu observasi langsung dan wawancara kepada setiap pemilik usaha dendeng yang akan dijadikan sampel penelitian, jenid data yang dibutuhkan seperti jumlah penjualan dendeng dalam satu periode tertentu, biaya-biaya yang dikeluarkan dalam proses produksi, harga jual produk, harga pokok produksi, serta data keuangan maupun nonkeuangan yang diperlukan dalam penelitian.

\section{Penyajian Data Penelitian}

Data yang digunakan dalam penelitian adalah data primer yang di dapat melalu observasi langsung dan wawancara kepada setiap pemilik usaha dendeng yang akan dijadikan sampel penelitian, jenid data yang dibutuhkan seperti jumlah penjualan dendeng dalam satu periode tertentu, biaya-biaya yang dikeluarkan dalam proses produksi, harga jual produk, harga pokok produksi, serta data keuangan maupun nonkeuangan yang diperlukan dalam penelitian.

\section{Data Penjualan Dendeng Sapi}

Berikut adalah tabel data penjualan produk dedeng sapi pada UMKM dendeng sapi di Banda Aceh: 
Tabel 4.1

Data Penjualan Dendeng UMKM Gunung Seulawah

\begin{tabular}{|c|c|c|c|c|c|}
\hline No & Bulan Penjualan & Jumlah Terjual (kg) & Harga & & Penjualan \\
\hline 1 & Januari & 2,535 & $\operatorname{Rp} 240,000$ & $\mathrm{Rp}$ & $608,400,000$ \\
\hline 2 & Februari & 2,580 & $\operatorname{Rp} 240,000$ & $\mathrm{Rp}$ & $619,200,000$ \\
\hline 3 & Maret & 2,630 & $\operatorname{Rp} 240,000$ & $\mathrm{Rp}$ & $631,200,000$ \\
\hline 4 & April & 2,800 & $\operatorname{Rp} 240,000$ & $\mathrm{Rp}$ & $672,000,000$ \\
\hline 5 & Mei & 3,560 & $\operatorname{Rp} 240,000$ & $\mathrm{Rp}$ & $854,400,000$ \\
\hline 6 & Juni & 5,470 & $\operatorname{Rp} 240,000$ & $\mathrm{Rp}$ & $1,312,800,000$ \\
\hline 7 & Juli & 2,860 & Rp 240,000 & $\mathrm{Rp}$ & $686,400,000$ \\
\hline 8 & Agustus & 3,740 & Rp 240,000 & $\mathrm{Rp}$ & $897,600,000$ \\
\hline 9 & September & 4,150 & $\operatorname{Rp} 240,000$ & $\mathrm{Rp}$ & $996,000,000$ \\
\hline 10 & Oktober & 3,660 & $\operatorname{Rp} 240,000$ & $\mathrm{Rp}$ & $878,400,000$ \\
\hline 11 & November & 3,780 & $\operatorname{Rp} 240,000$ & $\mathrm{Rp}$ & $907,200,000$ \\
\hline 12 & Desember & 4,235 & $\operatorname{Rp} 240,000$ & $\mathrm{Rp}$ & $1,016,400,000$ \\
\hline \multicolumn{2}{|r|}{ Total } & 42,000 & & $\mathbf{R p}$ & $10,080,000,000$ \\
\hline
\end{tabular}

Sumber :UMKM sektor industri makanan (Dendeng Sapi) di kota Banda Aceh

Tabel 4.2

Data Penjualan Dendeng UMKM Bungong Jaroe

\begin{tabular}{|c|c|c|c|lr|}
\hline No & $\begin{array}{c}\text { Bulan } \\
\text { Penjualan }\end{array}$ & $\begin{array}{c}\text { Jumlah Terjual } \\
(\mathrm{kg})\end{array}$ & Harga & \multicolumn{2}{|c|}{ Penjualan } \\
\hline 1 & Januari & 1,035 & $\mathrm{Rp} \mathrm{220,000}$ & $\mathrm{Rp}$ & $227,700,000$ \\
\hline 2 & Februari & 1,086 & $\mathrm{Rp} \mathrm{220,000}$ & $\mathrm{Rp}$ & $238,920,000$ \\
\hline 3 & Maret & 1,125 & $\mathrm{Rp} 220,000$ & $\mathrm{Rp}$ & $247,500,000$ \\
\hline 4 & April & 1,374 & $\mathrm{Rp} 220,000$ & $\mathrm{Rp}$ & $302,280,000$ \\
\hline 5 & Mei & 1,745 & $\mathrm{Rp} 220,000$ & $\mathrm{Rp}$ & $383,900,000$ \\
\hline 6 & Juni & 2,355 & $\mathrm{Rp} 220,000$ & $\mathrm{Rp}$ & $518,100,000$ \\
\hline 7 & Juli & 1,185 & $\mathrm{Rp} \mathrm{220,000}$ & $\mathrm{Rp}$ & $260,700,000$ \\
\hline 8 & Agustus & 1,385 & $\mathrm{Rp} \mathrm{220,000}$ & $\mathrm{Rp}$ & $304,700,000$ \\
\hline 9 & September & 1,975 & $\mathrm{Rp} \mathrm{220,000}$ & $\mathrm{Rp}$ & $434,500,000$ \\
\hline 10 & Oktober & 1,265 & $\mathrm{Rp} \mathrm{220,000}$ & $\mathrm{Rp}$ & $278,300,000$ \\
\hline 11 & November & 1,485 & $\mathrm{Rp} 220,000$ & $\mathrm{Rp}$ & $326,700,000$ \\
\hline 12 & Desember & 1,985 & $\mathrm{Rp} 220,000$ & $\mathrm{Rp}$ & $436,700,000$ \\
\hline & Total & $\mathbf{1 8 , 0 0 0}$ & & $\mathrm{Rp}$ & $\mathbf{3 , 9 6 0 , 0 0 0 , 0 0 0}$ \\
\hline
\end{tabular}

Sumber :UMKM sektor industri makanan (Dendeng Sapi) di kota Banda Aceh 
Tabel 4.3

Data Penjualan Dendeng UMKM Rencong Aceh

\begin{tabular}{|c|c|c|lr|lr|}
\hline No & Bulan Penjualan & $\begin{array}{c}\text { Jumlah Terjual } \\
(\mathrm{kg})\end{array}$ & $\begin{array}{c}\text { Harga Jual Per } \\
\text { Unit }\end{array}$ & Total Penjualan (Rp) \\
\hline 1 & Januari & 90 & $\mathrm{Rp}$ & 240,000 & $\mathrm{Rp}$ & $21,600,000$ \\
\hline 2 & Februari & 92 & $\mathrm{Rp}$ & 240,000 & $\mathrm{Rp}$ & $22,080,000$ \\
\hline 3 & Maret & 93 & $\mathrm{Rp}$ & 240,000 & $\mathrm{Rp}$ & $22,320,000$ \\
\hline 4 & April & 98 & $\mathrm{Rp}$ & 240,000 & $\mathrm{Rp}$ & $23,520,000$ \\
\hline 5 & Mei & 104 & $\mathrm{Rp}$ & 240,000 & $\mathrm{Rp}$ & $24,960,000$ \\
\hline 6 & Juni & 120 & $\mathrm{Rp}$ & 240,000 & $\mathrm{Rp}$ & $28,800,000$ \\
\hline 7 & Juli & 94 & $\mathrm{Rp}$ & 240,000 & $\mathrm{Rp}$ & $22,560,000$ \\
\hline 8 & Agustus & 95 & $\mathrm{Rp}$ & 240,000 & $\mathrm{Rp}$ & $22,800,000$ \\
\hline 9 & September & 114 & $\mathrm{Rp}$ & 240,000 & $\mathrm{Rp}$ & $27,360,000$ \\
\hline 10 & Oktober & 94 & $\mathrm{Rp}$ & 240,000 & $\mathrm{Rp}$ & $22,560,000$ \\
\hline 11 & November & 96 & $\mathrm{Rp}$ & 240,000 & $\mathrm{Rp}$ & $23,040,000$ \\
\hline 12 & Desember & 110 & $\mathrm{Rp}$ & 240,000 & $\mathrm{Rp}$ & $26,400,000$ \\
\hline & Total & $\mathbf{1 , 2 0 0}$ & & & $\mathrm{Rp}$ & $\mathbf{2 8 8 , 0 0 0 , 0 0 0}$ \\
\hline
\end{tabular}

Sumber :UMKM sektor industri makanan (Dendeng Sapi) di kota Banda Aceh

Pada tabel 4.2 dan 4.2 dapat dilihatb jumlah penjualan perbualan setiap UMKM dendeng sapi yang akan dijadikan dalam sampel penelitian. Perusahaan yang bergerak dibidang industri bisa disebut juga sebagai perusahaan manufaktur yang pendapatan totalnya juga berasal dari penjualan. Dari 3 responden yang berupa UMKM dendeng sapi yang teliti terlihat bahwa total penjualan masing-masing UMKM memiliki jumlah penjualan yang sangat berbeda setiap tahunnya mulai dari UMKM Gunung Seulawah penjualan pertahunnya sebesar Rp .10.080.000.000, UMKM Bungong Jaroe sebesar Rp.3.960.000.000 per tahunnya, dan terakhir UMKM Rencong Aceh memiliki jumlah penjualan terkecil yaitu Rp.288.000.000 per tahunnya.

\section{Biaya-Biaya yang Di Klasifikasikan}

Biaya yang dikeluarkan oleh UMKM dendeng sapi di Kota Banda Aceh dikelompokkan berdasarkan fungsi pokok dan prilakunya dalam perusahaan yaitu biaya tetap yaitu biaya yang harus dikeluarkan meski tidak menerima orderan untuk dijual dan biaya variabel yaitu biaya yang terjadi untuk memproduksi produk makanan dan minuman dimana jumlah biaya ini dipengaruhi oleh jumlah volume pemesanan oleh pelanggan. Berikut adalah tabel daftar biaya-biaya yang terjadi selama periode tahun 2017.

Tabel 4.4

Biaya pada UMKM Dendeng Gunung Seulawah

\begin{tabular}{|l|lr|}
\hline \multicolumn{1}{|c|}{ Biaya } & \multicolumn{2}{|c|}{ Jumlah Biaya } \\
\hline Biaya Bahan Baku & Rp $7,410,443,000$ \\
\hline Biaya Kotak & Rp & $210,000,000$ \\
\hline Biaya Plastik & Rp & $6,160,000$ \\
\hline Biaya Tenaga Kerja Langsung & Rp & $162,000,000$ \\
\hline Biaya Rekening Listrik & Rp & $10,293,000$ \\
\hline Biaya Rekening Air & Rp & $3,795,000$ \\
\hline Total Biaya & Rp $\mathbf{7 , 8 0 2 , 6 9 1 , 0 0 0}$ \\
\hline
\end{tabular}

Sumber : UMKM sektor industri makanan (Dendeng Sapi) di kota Banda Aceh 
Tabel 4.5

Biaya pada UMKM Dendeng Bungong Jaroe

\begin{tabular}{|l|l|}
\hline \multicolumn{1}{|c|}{ Biaya } & \multicolumn{1}{c|}{ Jumlah Biaya } \\
\hline Biaya Bahan Baku & Rp. 2.801 .018 .000 \\
\hline Biaya Kotak & Rp. 49.500 .000 \\
\hline Biaya Plastik & Rp. 1.530 .000 \\
\hline Biaya Tenaga Kerja Langsung & Rp. 109.200 .000 \\
\hline $\begin{array}{l}\text { Biaya Tenaga Kerja Tidak } \\
\text { Langsung }\end{array}$ & Rp.30.000.000 \\
\hline Biaya Rekening Listrik & Rp.2.474.000 \\
\hline Total biaya & Rp.2.993.722.000 \\
\hline
\end{tabular}

Sumber :UMKM sektor industri makanan (Dendeng Sapi) di kota Banda Aceh

Tabel 4.6

Biaya pada UMKM Dendeng Rencong Aceh

\begin{tabular}{|l|l|}
\hline \multicolumn{1}{|c|}{ Biaya } & \multicolumn{1}{c|}{ Jumlah Biaya } \\
\hline Biaya Bahan Baku & Rp. $185,715,700$ \\
\hline Biaya Kotak & Rp. $4,800,000$ \\
\hline Biaya Plastik & Rp. 307,000 \\
\hline Biaya Tenaga Kerja Langsung & Rp. $32,400,000$ \\
\hline Biaya Rekening Listrik & Rp. 335,000 \\
\hline Total Biaya & Rp. $\mathbf{2 2 3 , 5 5 7 , 7 0 0}$ \\
\hline
\end{tabular}

Sumber :UMKM sektor industri makanan (Dendeng Sapi) di kota Banda Aceh

Dapat dilihat bahwa dari tabel diatas, biaya yang tertera merupakan jumlah biaya yang terjadi selama satu tahun pada masing-masing UMKM dendeng di Banda Aceh. UMKM Gunung Seulawah memiliki jumlah biaya sebesar Rp.7.802.691.000, sedangkan UMKM Bungong Jaroe memiliki jumlah biaya Rp.2.993.722.000 dan yang terakhir adalah UMKM Rencong Aceh memiliki jumlah biaya sebesar Rp.223.557.700. Ketiga UMKM memiliki jumlah biaya yang berbeda-beda dan memiliki perbandingan yang cukup jauh.
Data diatas menunjukan belum ada pemisahan antara biaya variabel atau biaya tetap yang ada di masingmasing UMKM yang akan di telitiserta ada beberapa biaya yang belum dihitung seperti biaya penyusutan, biaya perawatan mesin dan biaya-biaya lainnya. Data yang akan diolah dapat digunakan setelah adanya pemisahan biaya serta penambahan biaya-biaya yang belum dihitung oleh UMKM, oleh sebab itu telah dijabarkan semua perhitungan biaya yang dikeluarkan setiap UMKM serta pemisahan-pemisahan antara biaya variabel dan biaya tetap : 
Tabel 4.7

Penggolongan Biaya Variabel UMKM Dendeng Gunung Seulawah

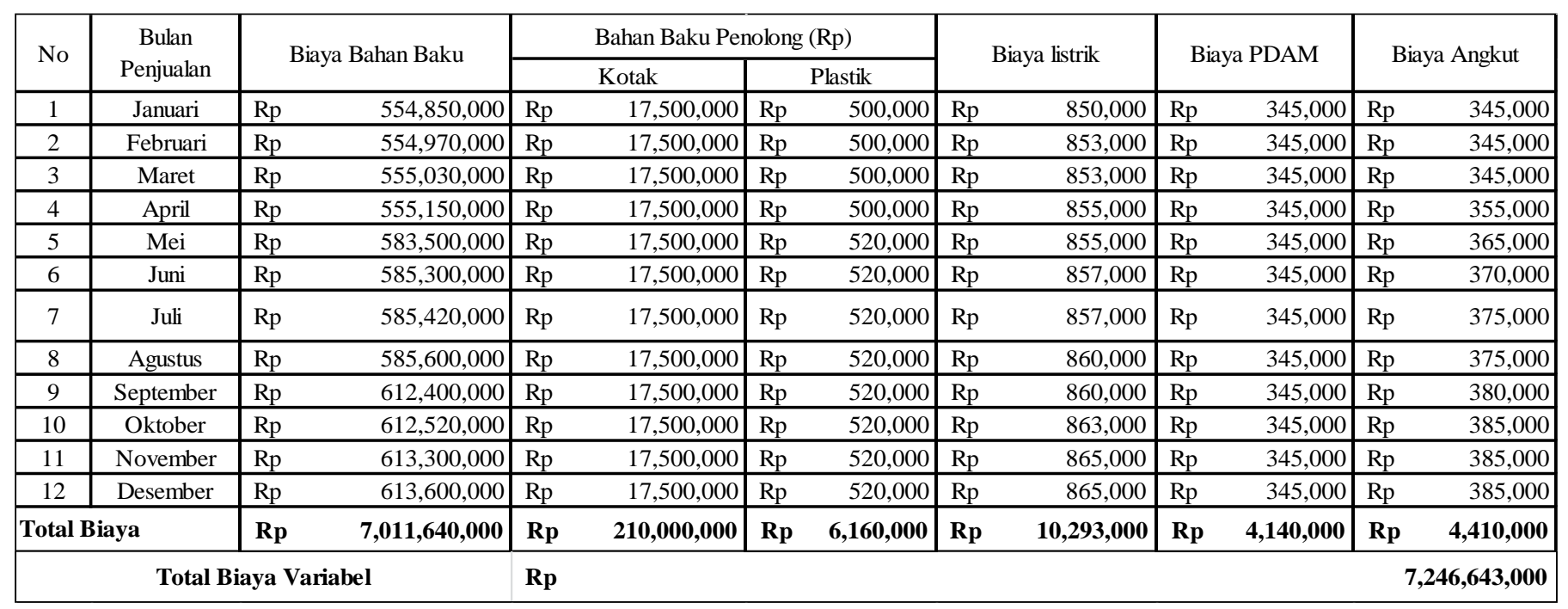

Sumber :UMKM sektor industri makanan (Dendeng Sapi) di kota Banda Aceh

Tabel 4.8

Biaya Tetap UMKM Dendeng Gunung Seulawah

\begin{tabular}{|c|c|c|c|c|c|}
\hline No & Bulan Penjualan & Biaya Perawatan Mesin & Biaya Penyusutan Mesin & Biaya Lainnya & Biaya Tenaga Kerja \\
\hline 1 & Januari & Rp150,000 & Rp 1,869,333 & $\operatorname{Rp} 4,500,000$ & Rp $13,500,000$ \\
\hline 2 & Februari & Rp 150,000 & $\operatorname{Rp} 1,869,333$ & $\mathrm{Rp} 4,500,000$ & $\operatorname{Rp} 13,500,000$ \\
\hline 3 & Maret & Rp 150,000 & Rp 1,869,333 & $\operatorname{Rp} 4,500,000$ & $\operatorname{Rp} 13,500,000$ \\
\hline 4 & April & Rp 150,000 & Rp 1,869,333 & $\operatorname{Rp} 4,500,000$ & Rp13,500,000 \\
\hline 5 & Mei & $\mathrm{Rp} \quad 150,000$ & Rp1,869,333 & Rp4,500,000 & Rp13,500,000 \\
\hline 6 & Juni & $\operatorname{Rp} 150,000$ & Rp1,869,333 & $\operatorname{Rp} 8,700,000$ & Rp13,500,000 \\
\hline 7 & Juli & Rp 150,000 & Rp1,869,333 & $\mathrm{Rp} 4,500,000$ & Rp 13,500,000 \\
\hline 8 & Agustus & Rp150,000 & Rp1,869,333 & Rp4,650,000 & Rp $13,500,000$ \\
\hline 9 & September & Rp 150,000 & Rp1,869,333 & $\mathrm{Rp} 4,650,000$ & Rp 13,500,000 \\
\hline 10 & Oktober & Rp 150,000 & Rp1,869,333 & $\mathrm{Rp} 4,650,000$ & Rp13,500,000 \\
\hline 11 & November & Rp 150,000 & Rp 1,869,333 & $\operatorname{Rp} 4,650,000$ & Rp 13,500,000 \\
\hline 12 & Desember & Rp 150,000 & Rp 1,869,333 & Rp4,650,000 & $\mathrm{R} 13,500,000$ \\
\hline & Total Biaya & Rp 1,800,000 & Rp 22,432,000 & Rp 8,950,000 & Rp 162,000,000 \\
\hline \multicolumn{3}{|c|}{ Total biaya Tetap } & \multicolumn{2}{|c|}{ Rp 245,182,000 } & \\
\hline
\end{tabular}

Sumber :UMKM sektor industri makanan (Dendeng Sapi) di kota Banda Aceh 
Tabel 4.9

Penggolongan Biaya Variabel UMKM Dendeng Bungong Jaroe

\begin{tabular}{|c|c|c|c|c|c|c|c|c|c|}
\hline \multirow{3}{*}{$\begin{array}{r}\text { No } \\
1\end{array}$} & \multirow{3}{*}{$\begin{array}{c}\begin{array}{c}\text { Bulan } \\
\text { Penjualan }\end{array} \\
\text { Januari }\end{array}$} & \multirow{2}{*}{\multicolumn{2}{|c|}{ Biaya Bahan Baku }} & \multicolumn{3}{|c|}{ Bahan Baku Penolong (Rp) } & \multirow{2}{*}{\multicolumn{2}{|c|}{ Biaya listrik }} & \multirow{2}{*}{ Biaya Angkut } \\
\hline & & & & \multicolumn{2}{|r|}{ Kotak } & Plastik & & & \\
\hline & & $\mathrm{Rp}$ & $221,147,500$ & $\mathrm{Rp}$ & $4,500,000$ & $\operatorname{Rp} \quad 125,000$ & $\mathrm{Rp}$ & 200,000 & Rp 220,000 \\
\hline 2 & Februari & $\mathrm{Rp}$ & $221,151,500$ & $\mathrm{Rp}$ & $4,500,000$ & $\operatorname{Rp} \quad 125,000$ & $\mathrm{Rp}$ & 200,000 & $\mathrm{Rp} \quad 220,000$ \\
\hline 3 & Maret & $\mathrm{Rp}$ & $221,153,500$ & $\mathrm{Rp}$ & $4,500,000$ & Rp $\quad 125,000$ & $\mathrm{Rp}$ & 200,000 & Rp $\quad 235,000$ \\
\hline 4 & April & $\mathrm{Rp}$ & $221,157,500$ & $\mathrm{Rp}$ & $4,500,000$ & Rp 125,000 & $\mathrm{Rp}$ & 200,000 & 235,000 \\
\hline 5 & Mei & $\mathrm{Rp}$ & $233,377,500$ & $\mathrm{Rp}$ & $4,500,000$ & Rp 127,500 & $\mathrm{Rp}$ & 208,000 & Rp $\quad 240,000$ \\
\hline 6 & Juni & $\mathrm{Rp}$ & $233,487,500$ & $\mathrm{Rp}$ & $4,500,000$ & $\operatorname{Rp} \quad 127,500$ & $\mathrm{Rp}$ & 208,000 & Rp $\quad 245,000$ \\
\hline 7 & Juli & $\mathrm{Rp}$ & $233,491,500$ & $\mathrm{Rp}$ & $4,500,000$ & $\mathrm{Rp} \quad 127,500$ & $\mathrm{Rp}$ & 210,000 & 245,000 \\
\hline 8 & Agustus & $\mathrm{Rp}$ & $233,497,500$ & $\mathrm{Rp}$ & $4,500,000$ & $\mathrm{Rp} \quad 127,500$ & $\mathrm{Rp}$ & 210,000 & $\mathrm{Rp} \quad 250,000$ \\
\hline 9 & September & $\mathrm{Rp}$ & $245,607,500$ & $\mathrm{Rp}$ & $4,500,000$ & Rp $\quad 130,000$ & $\mathrm{Rp}$ & 212,000 & 245,000 \\
\hline 10 & Oktober & $\mathrm{Rp}$ & $245,611,500$ & $\mathrm{Rp}$ & $4,500,000$ & Rp 130,000 & $\mathrm{Rp}$ & 208,000 & Rp $\quad 250,000$ \\
\hline 11 & November & $\mathrm{Rp}$ & $245,657,500$ & $\mathrm{Rp}$ & $4,500,000$ & $\mathrm{Rp} \quad 130,000$ & $\mathrm{Rp}$ & 208,000 & Rp 255,000 \\
\hline 12 & Desember & $\mathrm{Rp}$ & $245,677,500$ & $\mathrm{Rp}$ & $4,500,000$ & $\mathrm{Rp} \quad 130,000$ & $\mathrm{Rp}$ & 210,000 & 265,000 \\
\hline \multicolumn{2}{|c|}{ Total Biaya } & $\mathbf{R p}$ & $2,801,018,000$ & $\mathbf{R p}$ & $54,000,000$ & Rp 1,530,000 & $\mathbf{R p}$ & $2,474,000$ & Rp 2,905,000 \\
\hline \multicolumn{4}{|c|}{ Total Biaya Variabel } & \multicolumn{3}{|l|}{$\mathbf{R p}$} & & & $2,861,927,000$ \\
\hline
\end{tabular}

Sumber :UMKM sektor industri makanan (Dendeng Sapi) di kota Banda Aceh

Tabel 4.10

Biaya tetap UMKM Dendeng Bungong Jaroe

\begin{tabular}{|c|c|c|c|c|c|c|c|c|c|c|c|}
\hline \multirow{2}{*}{$\frac{\text { No }}{1}$} & \multirow{2}{*}{$\begin{array}{c}\begin{array}{c}\text { Bulan } \\
\text { Penjualan }\end{array} \\
\text { Januari }\end{array}$} & \multicolumn{2}{|c|}{$\begin{array}{c}\text { Biaya Perawatan } \\
\text { Mesin }\end{array}$} & \multicolumn{2}{|c|}{$\begin{array}{c}\text { Biaya Penyusutan } \\
\text { Mesin }\end{array}$} & \multicolumn{2}{|c|}{ Biaya Lainnya } & \multicolumn{2}{|c|}{$\begin{array}{c}\text { Biaya tenaga kerja } \\
\text { produksi }\end{array}$} & \multicolumn{2}{|c|}{$\begin{array}{l}\text { Biaya tenaga kerja } \\
\text { tidak langsung }\end{array}$} \\
\hline & & $\mathrm{Rp}$ & 50,000 & $\mathrm{Rp}$ & 507,188 & $\mathrm{Rp}$ & $2,850,000$ & $\mathrm{Rp}$ & $9,100,000$ & $\mathrm{Rp}$ & $2,500,000$ \\
\hline 2 & Februari & $\mathrm{Rp}$ & 50,000 & $\mathrm{Rp}$ & 507,188 & $\mathrm{Rp}$ & $2,850,000$ & $\mathrm{Rp}$ & $9,100,000$ & $\mathrm{Rp}$ & $2,500,000$ \\
\hline 3 & Maret & $\mathrm{Rp}$ & 50,000 & $\mathrm{Rp}$ & 507,188 & $\mathrm{Rp}$ & $2,850,000$ & $\mathrm{Rp}$ & $9,100,000$ & $\mathrm{Rp}$ & $2,500,000$ \\
\hline 4 & April & $\mathrm{Rp}$ & 50,000 & $\mathrm{Rp}$ & 507,188 & $\mathrm{Rp}$ & $2,850,000$ & $\mathrm{Rp}$ & $9,100,000$ & $\mathrm{Rp}$ & $2,500,000$ \\
\hline 5 & Mei & $\mathrm{Rp}$ & 60,000 & $\mathrm{Rp}$ & 507,188 & $\mathrm{Rp}$ & $2,850,000$ & $\mathrm{Rp}$ & $9,100,000$ & $\mathrm{Rp}$ & $2,500,000$ \\
\hline 6 & Juni & $\mathrm{Rp}$ & 60,000 & $\mathrm{Rp}$ & 507,188 & $\mathrm{Rp}$ & $5,200,000$ & $\mathrm{Rp}$ & $9,100,000$ & $\mathrm{Rp}$ & $2,500,000$ \\
\hline 7 & Juli & $\mathrm{Rp}$ & 60,000 & $\mathrm{Rp}$ & 507,188 & $\mathrm{Rp}$ & $2,850,000$ & $\mathrm{Rp}$ & $9,100,000$ & $\mathrm{Rp}$ & $2,500,000$ \\
\hline 8 & Agustus & $\mathrm{Rp}$ & 60,000 & $\mathrm{Rp}$ & 507,188 & $\mathrm{Rp}$ & $2,850,000$ & $\mathrm{Rp}$ & $9,100,000$ & $\mathrm{Rp}$ & $2,500,000$ \\
\hline 9 & September & $\mathrm{Rp}$ & 65,000 & $\mathrm{Rp}$ & 507,188 & $\mathrm{Rp}$ & $2,850,000$ & $\mathrm{Rp}$ & $9,100,000$ & $\mathrm{Rp}$ & $2,500,000$ \\
\hline 10 & Oktober & $\mathrm{Rp}$ & 65,000 & $\mathrm{Rp}$ & 507,188 & $\mathrm{Rp}$ & $2,850,000$ & $\mathrm{Rp}$ & $9,100,000$ & $\mathrm{Rp}$ & $2,500,000$ \\
\hline 11 & November & $\mathrm{Rp}$ & 65,000 & $\mathrm{Rp}$ & 507,188 & $\mathrm{Rp}$ & $2,850,000$ & $\mathrm{Rp}$ & $9,100,000$ & $\mathrm{Rp}$ & $2,500,000$ \\
\hline 12 & Desember & $\mathrm{Rp}$ & 65,000 & $\mathrm{Rp}$ & 507,188 & $\mathrm{Rp}$ & $2,850,000$ & $\mathrm{Rp}$ & $9,100,000$ & $\mathrm{Rp}$ & $2,500,000$ \\
\hline \multicolumn{2}{|c|}{ Total Biaya } & $\mathbf{R p}$ & 700,000 & $\mathbf{R p}$ & $6,086,250$ & $\mathbf{R p}$ & $36,550,000$ & $\mathbf{R p}$ & $09,200,000$ & $\mathbf{R p}$ & $30,000,000$ \\
\hline \multicolumn{4}{|c|}{ Total Biaya Tetap } & \multicolumn{4}{|l|}{$\mathbf{R p}$} & & & \multicolumn{2}{|r|}{$182,536,250$} \\
\hline
\end{tabular}

Sumber : UMKM sektor industri makanan (Dendeng Sapi) di kota Banda Aceh 
Tabel 4.11

Biaya Variabel UMKM Rencong Aceh

\begin{tabular}{|c|c|c|c|c|c|c|c|c|c|c|}
\hline \multirow{3}{*}{$\begin{array}{l}\text { No } \\
1\end{array}$} & \multirow{3}{*}{$\begin{array}{c}\begin{array}{c}\text { Bulan } \\
\text { Penjualan }\end{array} \\
\text { Januari }\end{array}$} & \multirow{2}{*}{\multicolumn{2}{|c|}{ Biaya Bahan Baku }} & \multicolumn{4}{|c|}{ Bahan Baku Penolong (Rp) } & \multirow{2}{*}{\multicolumn{2}{|c|}{ Biaya Listrik }} & \multirow{2}{*}{ Biaya Angkut } \\
\hline & & & & \multicolumn{2}{|c|}{ Kotak } & \multicolumn{2}{|c|}{ Plastik } & & & \\
\hline & & $\mathrm{Rp}$ & $14,829,500$ & $\mathrm{Rp}$ & 400,000 & $\mathrm{Rp}$ & 25,000 & $\mathrm{Rp}$ & 23,000 & Rp 105,000 \\
\hline 2 & Februari & $\mathrm{Rp}$ & $14,832,100$ & $\mathrm{Rp}$ & 400,000 & $\mathrm{Rp}$ & 25,000 & $\mathrm{Rp}$ & 25,000 & Rp 105,000 \\
\hline 3 & Maret & $\mathrm{Rp}$ & $14,833,400$ & $\mathrm{Rp}$ & 400,000 & $\mathrm{Rp}$ & 25,000 & $\mathrm{Rp}$ & 25,000 & Rp 105,000 \\
\hline 4 & April & $\mathrm{Rp}$ & $14,836,000$ & $\mathrm{Rp}$ & 400,000 & $\mathrm{Rp}$ & 25,000 & $\mathrm{Rp}$ & 27,000 & $\mathrm{Rp} \quad 105,000$ \\
\hline 5 & Mei & $\mathrm{Rp}$ & $15,573,000$ & $\mathrm{Rp}$ & 400,000 & $\mathrm{Rp}$ & 25,000 & $\mathrm{Rp}$ & 27,000 & $\mathrm{Rp} \quad 105,000$ \\
\hline 6 & Juni & $\mathrm{Rp}$ & $15,590,000$ & $\mathrm{Rp}$ & 400,000 & $\mathrm{Rp}$ & 26,000 & $\mathrm{Rp}$ & 28,000 & Rp 105,000 \\
\hline 7 & Juli & $\mathrm{Rp}$ & $15,592,600$ & $\mathrm{Rp}$ & 400,000 & $\mathrm{Rp}$ & 26,000 & $\mathrm{Rp}$ & 28,000 & Rp 105,000 \\
\hline 8 & Agustus & $\mathrm{Rp}$ & $15,596,500$ & $\mathrm{Rp}$ & 400,000 & $\mathrm{Rp}$ & 26,000 & $\mathrm{Rp}$ & 30,000 & Rp 105,000 \\
\hline 9 & September & $\mathrm{Rp}$ & $16,002,000$ & $\mathrm{Rp}$ & 400,000 & $\mathrm{Rp}$ & 26,000 & $\mathrm{Rp}$ & 30,000 & Rp 105,000 \\
\hline 10 & Oktober & $\mathrm{Rp}$ & $16,004,600$ & $\mathrm{Rp}$ & 400,000 & $\mathrm{Rp}$ & 26,000 & $\mathrm{Rp}$ & 30,000 & $\mathrm{Rp} \quad 105,000$ \\
\hline 11 & November & $\mathrm{Rp}$ & $16,012,100$ & $\mathrm{Rp}$ & 400,000 & $\mathrm{Rp}$ & 26,000 & $\mathrm{Rp}$ & 32,000 & Rp $\quad 105,000$ \\
\hline 12 & Desember & $\mathrm{Rp}$ & $16,013,900$ & $\mathrm{Rp}$ & 400,000 & $\mathrm{Rp}$ & 26,000 & $\mathrm{Rp}$ & 32,000 & $\mathrm{Rp} \quad 105,000$ \\
\hline & Total & $\mathbf{R p}$ & $185,715,700$ & $\mathbf{R p}$ & $, 800,000$ & $\mathbf{R p}$ & 307,000 & & 37,000 & Rp1,260,000 \\
\hline \multicolumn{4}{|c|}{ Total biaya variabel } & \multicolumn{6}{|l|}{$\mathbf{R p}$} & $192,419,700$ \\
\hline
\end{tabular}

Sumber :UMKM sektor industri makanan (Dendeng Sapi) di kota Banda Aceh

Tabel 4.12

Biaya Tetap UMKM Rencong Aceh

\begin{tabular}{|c|c|c|c|c|c|c|c|c|c|}
\hline No & $\begin{array}{c}\text { Bulan } \\
\text { Penjualan }\end{array}$ & & $\begin{array}{l}\text { jiaya } \\
\text { awatan } \\
\text { Lesin }\end{array}$ & & $\begin{array}{l}\text { Biaya } \\
\text { yusutan } \\
\text { Desin }\end{array}$ & Biay & Lainnya & & $\begin{array}{l}\text { ya Tenaga } \\
\text { Kerja }\end{array}$ \\
\hline 1 & Januari & & 20,000 & $\mathrm{Rp}$ & 416,250 & $\mathrm{Rp}$ & 70,000 & $\mathrm{Rp}$ & $2,700,000$ \\
\hline 2 & Februari & $\mathrm{Rp}$ & 20,000 & $\mathrm{Rp}$ & 416,250 & $\mathrm{Rp}$ & 70,000 & $\mathrm{Rp}$ & $2,700,000$ \\
\hline 3 & Maret & $\mathrm{Rp}$ & 20,000 & $\mathrm{Rp}$ & 416,250 & $\mathrm{Rp}$ & 70,000 & $\mathrm{Rp}$ & $2,700,000$ \\
\hline 4 & April & $\mathrm{Rp}$ & 20,000 & $\mathrm{Rp}$ & 416,250 & $\mathrm{Rp}$ & 70,000 & $\mathrm{Rp}$ & $2,700,000$ \\
\hline 5 & Mei & $\mathrm{Rp}$ & 25,000 & $\mathrm{Rp}$ & 416,250 & $\mathrm{Rp}$ & 70,000 & $\mathrm{Rp}$ & $2,700,000$ \\
\hline 6 & Juni & $\mathrm{Rp}$ & 25,000 & $\mathrm{Rp}$ & 416,250 & $\mathrm{Rp}$ & 350,000 & $\mathrm{Rp}$ & $2,700,000$ \\
\hline 7 & Juli & $\mathrm{Rp}$ & 20,000 & $\mathrm{Rp}$ & 416,250 & $\mathrm{Rp}$ & 70,000 & $\mathrm{Rp}$ & $2,700,000$ \\
\hline 8 & Agustus & $\mathrm{Rp}$ & 20,000 & $\mathrm{Rp}$ & 416,250 & $\mathrm{Rp}$ & 70,000 & $\mathrm{Rp}$ & $2,700,000$ \\
\hline 9 & September & $\mathrm{Rp}$ & 25,000 & $\mathrm{Rp}$ & 416,250 & $\mathrm{Rp}$ & 70,000 & $\mathrm{Rp}$ & $2,700,000$ \\
\hline 10 & Oktober & $\mathrm{Rp}$ & 20,000 & $\mathrm{Rp}$ & 416,250 & $\mathrm{Rp}$ & 70,000 & $\mathrm{Rp}$ & $2,700,000$ \\
\hline 11 & November & $\mathrm{Rp}$ & 20,000 & $\mathrm{Rp}$ & 416,250 & $\mathrm{Rp}$ & 70,000 & $\mathrm{Rp}$ & $2,700,000$ \\
\hline 12 & Desember & $\mathrm{Rp}$ & 20,000 & $\mathrm{Rp}$ & 416,250 & $\mathrm{Rp}$ & 70,000 & $\mathrm{Rp}$ & $2,700,000$ \\
\hline & Total & $\mathbf{R p}$ & 255,000 & $\mathbf{R p}$ & $4,995,000$ & $\mathbf{R p}$ &, $\mathbf{1 2 0 , 0 0 0}$ & $\mathbf{R p}$ & $32,400,000$ \\
\hline \multicolumn{4}{|c|}{ Total Biaya Tetap } & \multicolumn{4}{|c|}{$\mathbf{R p}$} & \multicolumn{2}{|r|}{$38,770,000$} \\
\hline
\end{tabular}

Sumber :UMKM sektor industri makanan (Dendeng Sapi) di kota Banda Aceh 
Pada Tabel 4.6, 4.7, 4.8, 4.9, 4.10, 4.11 dapat dilihat bahwa setiap usaha juga memiliki perbedaan jumlah antara biaya tetap maupun biaya variabelnya. Jumlah biaya variabel di tahun 2017 pada UMKM Gunung Seulawah senilai Rp. Rp. 7.246.643.000,00 sedangkan biaya tetapnya sebesar Rp.245.182.000,00. Pada UMKM dendeng Bungong Jaroe jumlah biaya variabelnya senilai Rp. 2.857.427.000,00 dan biaya tetapnya Rp. 182.536.250,00 pada tahun 2017. UMKM Rencong Aceh memilki jumlah biaya variabel pada tahun 2017 sebesar Rp. 192.419.700,00 dan biaya tetapnya Rp. 38.770.000,00.

\section{Pembahasan}

\section{Analisis CVP (Cost Volume Profit)}

Dalam melakukan analisis CPV pada UMKM dendeng yang ada di banda aceh yang terdiri dari UMKM Gunung Seulawah, UMKM Bungong Jaroe dan UMKM Rencong Aceh. Alat dalam melakukan analisis CPV adalah CM, BEP, MOS dan yang terakhir adalah OL.

\section{CM (Contribution Margin)}

CM yang merupakan selisih antara harga jual dan biaya variabel. Rumus CM per unit dapat dihitung sebagai berikut:

\section{Margin Kontribusi = Penjualan - Biaya Variabel}

Saat Menghitung Rasio Margin Kontribusi adalah $100 \%$ dikurang dengan biaya variabel yang dibagi dengan harga jual, Dapat dihitung dengan rumus sebagai berikut :

\section{Rasio = Total CM / Total Penjualan}

Tabel 4. 13

Contribution Margin Pada UMKM Dendeng Sapi (Sebelum Menggunakan CPV)

\begin{tabular}{|c|c|c|c|c|c|c|c|}
\hline \multirow{3}{*}{$\begin{array}{l}\text { UMKM } \\
\text { Gunung } \\
\text { Seulawah }\end{array}$} & \multicolumn{2}{|c|}{ Penjualan Dendeng } & \multicolumn{2}{|c|}{ Beban Variabel } & \multirow{2}{*}{\multicolumn{2}{|c|}{ Contribution Margin (Rp) }} & \multirow{3}{*}{$\begin{array}{l}\begin{array}{l}\text { Rasio } \\
\text { CM } \\
(\%)\end{array} \\
28 \%\end{array}$} \\
\hline & Total & Per Unit & Total & Per Unit & & & \\
\hline & Rp.10.080.000.000 & Rp. 240.000 & Rp 7,242,233,000 & Rp.172,434 & $\operatorname{Rp} 2,837,767,000$ & $\operatorname{Rp} 67,566$ & \\
\hline $\begin{array}{l}\text { Bungong } \\
\text { Jaroe }\end{array}$ & Rp.3.960.000.000 & Rp.220.000 & $\mathrm{Rp} \quad 2,859,022,000$ & Rp 158,835 & Rp 1,100,978,000 & $\operatorname{Rp} 61,165$ & $28 \%$ \\
\hline $\begin{array}{l}\text { Rencong } \\
\text { Aceh }\end{array}$ & Rp.288.000.000, & Rp.240.000 & Rp 191,159,700 & Rp 159,300 & Rp 96,840,300 & $\operatorname{Rp} 80,700$ & $34 \%$ \\
\hline
\end{tabular}

Sumber : Data diolah 2018

Tabel 4. 14

Contribution Margin Pada UMKM Dendeng Sapi (Sesudah Menggunakan CPV)

\begin{tabular}{|c|c|c|c|c|c|c|c|}
\hline \multirow{3}{*}{$\begin{array}{l}\text { UMKM } \\
\text { Gunung } \\
\text { Seulawah }\end{array}$} & \multicolumn{2}{|c|}{ Penjualan Dendeng } & \multicolumn{2}{|c|}{ Beban Variabel } & \multirow{2}{*}{\multicolumn{2}{|c|}{$\begin{array}{l}\text { Contribution Margin } \\
\text { (Rp) }\end{array}$}} & \multirow{3}{*}{$\begin{array}{l}\text { Rasio } \\
\text { CM } \\
(\%)\end{array}$} \\
\hline & Total & Per Unit & Total & Per Unit & & & \\
\hline & Rp.10.080.000.000 & Rp. 240.000 & $\operatorname{Rp} 7,246,643,000$ & Rp 172,539 & $\operatorname{Rp} 2,833,357,000$ & $\operatorname{Rp} 67,461$ & \\
\hline $\begin{array}{l}\text { Bungong } \\
\text { Jaroe }\end{array}$ & Rp.3.960.000.000 & Rp.220.000 & Rp $2,857,427,000$ & Rp 158,746 & Rp 1,102,573,000 & Rp 61,254.06 & $28 \%$ \\
\hline $\begin{array}{l}\text { Rencong } \\
\text { Aceh }\end{array}$ & Rp.288.000.000, & Rp. 240.000 & Rp 192,419,700.00 & Rp 160,350 & Rp 95,580,300 & Rp.79,650.25 & $33 \%$ \\
\hline
\end{tabular}

Sumber : Data diolah 2018 
Dari data tabel 4.12 maka dapat diperoleh hasil perhitungan $\mathrm{CM}$ per unit pada setiap $\mathrm{kg}$ dendeng sapi pada UMKM Gunung Seualawah sebelum menggunakan CPV sebesar Rp 2.837.767.000,00sedangkan setelah menggunakan CPV jumlah biaya variabelnya sebesar $\operatorname{Rp} 2.833 .357 .000,00$ - dengan nilai Rasio CM yang sama yaitu $28 \%$, selanjutnya pada UMKM Bungong Jaroe memiliki nilai CM sebelum menggunakan CPV sebesar RP 1.100.978.000,00sedangkan setelah menggunakan CPV biaya variabelnya sebesar Rp 1.102.573.000,00- didampingi dengan nilai Rasio CM nya yang sama yaitu sebesar 28\% dan yang terakhir UMKM Rencong Aceh memiliki nilai $\mathrm{CM}$ sebelum analisis CPV sebesar Rp 96.840.300,00- dan nilai biaya variabel setelah menggunakan CPV sebesar Rp 95,580,300 dan nilai Rasio CM yang sama sebesar $33 \%$.

Data tabel tersebut menunujukan bahwa tiap persen nilai rasio CM maka setiap kenaikan penjualan (dalam Rp) maka total CM juga akan naik sebsar berapa persen kenaikan penjualan serta laba bersih juga pasti akan mengalami peningkatan dengan asumsi jumlah biaya tetap konstan (tidak berubah). Pada nilai CM masing-masing UMKM menunjukan nilai lebih besar dari biaya tetap yang ada di perusahaa maka perusahaan sudah pasti tidak dalam keadaan rugi dan tetap mendapatkan keuntungan, tetapi bila nilai $\mathrm{CM}$ sebuah UMKM sama dengan jumlah biaya tetap perusahaannya itu menunjukan bahwa unit usaha sedang mengalami BEP atau dalam titk impas, dan juka margin kontribusinya lebih rendah dari biaya tetap perusahaan maka perusahaan mengalami kerugian.

\section{BEP (Break Even Point)}

BEP atau titik impas didefinisikan titik impas dimana pada tingkat penjualan laba yang didapatkan sama dengan nol dengan kata lain dimana perusahaan tidak mengalami keerugian atau mendapatkan keuntungan (Garisson, Noreen dan Brewer 2014:224). Analisis BEP merupakan alat peling penting di dalam analisi CVP. Berikut BEP atas dasar nilai uang dapat diperoleh menggunakan rumus :

Titik impas dalam penjualan (Rp)

BEP $($ Rp $)=$ Biaya Tetap $/$ Rasio Margin Konrtribusi

\section{Rasio Kontribusi Margin = Contribusi Margin / Penjualan}

Titik impas dalam unit penjualan (unit)

Bep $($ Unit $)=$ Biaya Tetap $/$ Margin Kontrubusi Per Unit

Tabel 4.15

Hasil Perhitungan BEP pada setiap UMKM dendeng sapi (Sebelum Menggunakan CPV)

\begin{tabular}{|c|c|l|c|c|}
\hline No & Nama UMKM & $\begin{array}{c}\text { Penjualan Dalam } \\
\text { Keadaan BEP(Rp) }\end{array}$ & $\begin{array}{c}\text { Penjualan Dalam } \\
\text { Keadaan BEP(Unit) }\end{array}$ & Keterangan \\
\hline 1 & Gunung Seulawah & Rp. 575,438,364 & 2,398 & BEP \\
\hline 2 & Bungong Jaroe & Rp. 500,674,855 & 2,276 & BEP \\
\hline 3 & Rencong Aceh & Rp. $96,356,579$ & 401 & BEP \\
\hline & Rata-rata & Rp 390,823,266 & 1,692 & BEP \\
\hline
\end{tabular}

Sumber : data diolah 2018

Tabel 4.16

Hasil Perhitungan BEP pada setiap UMKM dendeng sapi (Sesudah Menggunakan CPV)

\begin{tabular}{|c|c|c|c|c|}
\hline No & Nama UMKM & $\begin{array}{l}\text { Penjualan Dalam } \\
\text { Keadaan BEP (Rp) }\end{array}$ & $\begin{array}{c}\text { Penjualan Dalam } \\
\text { Keadaan BEP } \\
\text { (Unit) }\end{array}$ & Keterangan \\
\hline 1 & Gunung Seulawah & Rp $872,263,735$ & 3,634 & BEP \\
\hline 2 & Bungong Jaroe & Rp 655,596,999 & 2,980 & BEP \\
\hline 3 & Rencong Aceh & Rp 116,820,726 & 487 & BEP \\
\hline & Rata-rata & Rp 548,227,153 & 1,156 & BEP \\
\hline
\end{tabular}

Sumber : data diolah 2018 
Berdasarkan hasil perhitungan BEP atau titik impas dalam satuan uang maupun satuan unit dari 3 unit usaha dendeng sapi yang ada di Banda Aceh, ratarata jumlah penjualan dalam keadaan BEP sebelum menggunakan CPV sebesar Rp 390.823.266,00dengan penjualan dalam keadaan BEP dalam unit sebesar 1,692 dan rata-rata jumlah penjualan dalam keadaan BEP sesudah menggunakan CPV sebesar Rp 548.227.153,00- dengan penjualan dalam keadaan BEP dalam unit sebesar 1,156 unit, Sedangkan dilihat dari hasil perhitungan BEP bahwa setiap UMKM telah melewati batas BEP tahun ini dan sudah pasti perusahaan dalam keadaaan mendapatkan keuntungan.

\section{MOS (Margin Of Safety)}

MOS merupakan jumlah penjualan yang direncanakan di atas titik impas (Blocher et al,. 2011 :
525). MOS adalah jumlah penjualan yang dapat menurun sebelum kerugian mulai terjadi. Sehingga semakin tinggi batas keamanan, semakin rendah risiko suatu perusahaan tidak mencapai titik impas (Garisson, Noreen dan Brewer 2014:225). MOS dapat dihitung menggunakan rumus sebagai berikut:

\section{MOS = penjualan aktual - BEP}

Biasanya MOS dapat disajikan dalam bentuk persentase dengan membagi MOS dalam nilai uang dengan total nilai penjualan dalam satuan uang, sebagai berikut :

$\operatorname{MOS}(\%)=$ MOS $/$ total penjualan yang dianggarkan (actual)

Tabel 4.17

Margin Of Safety Pada UMKM Dendeng Sapi

(Sebelum Menggunakan CPV)

\begin{tabular}{|c|c|c|c|c|c|c|c|c|c|}
\hline \multirow{2}{*}{ No } & \multirow{2}{*}{ Umkm } & \multicolumn{2}{|c|}{ Penjualan Aktual } & \multicolumn{2}{|c|}{ Penjualan Saat BEP } & \multicolumn{2}{|l|}{ MOS } & \multicolumn{2}{|c|}{$\%$ MOS } \\
\hline & & $(\mathbf{R p})$ & (Unit) & (Rp) & (Unit) & $(\mathbf{R p})$ & (Unit) & $(\mathbf{R p})$ & (Unit) \\
\hline 1 & Gunung Seulawah & Rp.10.080.000.000 & 42.000 & Rp.575,438,364 & 2,398 & Rp 9,504,561,636 & 39,602 & $94 \%$ & $94 \%$ \\
\hline 2 & Bungong Jaroe & Rp.3.960.000.000 & 18.000 & Rp.500,674,855 & 2,276 & Rp 3,459,325,145 & 15,724 & $87 \%$ & $87 \%$ \\
\hline 3 & Rencong Aceh & Rp.288.000.000 & 1.200 & Rp. $96,356,579$ & 401 & Rp 191,643,421 & 799 & $67 \%$ & $67 \%$ \\
\hline
\end{tabular}

Sumber : data diolah 2018

Tabel 4.18

Margin Of Safety Pada UMKM Dendeng Sapi

(Sesudah Menggunakan CPV)

\begin{tabular}{|c|c|c|c|c|c|c|c|c|c|}
\hline \multirow{2}{*}{ No } & \multirow{2}{*}{ Umkm } & \multicolumn{2}{|c|}{ Penjualan Aktual } & \multicolumn{2}{|c|}{ Penjualan Saat BEP } & \multicolumn{2}{|l|}{ Mos } & \multicolumn{2}{|c|}{$\%$ MOS } \\
\hline & & $(\mathbf{R p})$ & (Unit) & $(\mathbf{R p})$ & (Unit) & (Rp) & (Unit) & $(\mathbf{R p})$ & (Unit) \\
\hline 1 & Gunung Seulawah & Rp.10.080.000.000 & 42.000 & Rp 872,263,735 & 3,634 & Rp 9,207,736,265 & 38,366 & $91 \%$ & $91 \%$ \\
\hline 2 & Bungong Jaroe & Rp.3.960.000.000 & 18.000 & Rp 655,596,999 & 2,980 & Rp 3,304,403,000 & 15,020 & $83 \%$ & $83 \%$ \\
\hline 3 & Rencong Aceh & Rp.288.000.000 & 1.200 & Rp 116,820,726 & 487 & Rp 171,179,274 & 713 & $59 \%$ & $59 \%$ \\
\hline
\end{tabular}

Sumber : data diolah 2018

\section{OP (Operating Laverage)}

OL merupakan suatu jkuran mengenai seberapa sensitive laba operasi perusahaan terhadap perubahan persentase dalam nilai penjualan (Garisson, Noreen dan Brewer 2014:225). Nilai OL yang tinggi akan menunjukan kecilnya peningkatan persentase dalam penjualan dalam menghasilkan peningkatan persentase laba bersih lebih besar. Tingkat leverage operasi menghasilkan rumus berikut :

Degree of operating = Contribution Margin $/$ Laba 
Tabel 4.19

Tingkat Laverage Operasi UMKM Dendeng Sapi (Sebelum Menggunakan CPV)

\begin{tabular}{|c|c|c|c|}
\hline UMKM & Gunung Seulawah & Bungong Jaroe & Rencong Aceh \\
\hline Penjualan & $\operatorname{Rp~} 10,080,000,000$ & $\operatorname{Rp~3,960,000,000}$ & $\operatorname{Rp~288,000,000}$ \\
\hline Beban Variabel & $\operatorname{Rp~} 7,242,233,000$ & $\operatorname{Rp~} 2,859,022,000$ & $\operatorname{Rp~191,159,700}$ \\
\hline Margin Kontribusi & $\operatorname{Rp~} 2,837,767,000$ & $\operatorname{Rp~} 1,100,978,000$ & $\operatorname{Rp~96,840,300}$ \\
\hline Beban Tetap & $\operatorname{Rp~} 162,000,000$ & $\operatorname{Rp~} 139,200,000$ & $\operatorname{Rp~32,400,000}$ \\
\hline Laba Neto Operasi & $\operatorname{Rp~} 2,675,767,000$ & $\operatorname{Rp~} 961,778,000$ & $\operatorname{Rp~64,440,300}$ \\
\hline Tingkat Laverage Operasi & $\mathbf{1 . 0 6}$ & $\mathbf{1 . 1 4}$ & $\mathbf{1 . 5 0}$ \\
\hline
\end{tabular}

Sumber : Data diolah 2018

Tabel 4.20

Tingkat Laverage Operasi UMKM Dendeng Sapi (Sesudah Menggunakan CPV)

\begin{tabular}{|c|c|c|c|}
\hline UMKM & Gunung Seulawah & Bungong Jaroe & Rencong Aceh \\
\hline Penjualan & $\operatorname{Rp~10,080,000,000}$ & $\operatorname{Rp~3,960,000,000}$ & $\operatorname{Rp~288,000,000}$ \\
\hline Beban Variabel & $\operatorname{Rp~7,246,643,000}$ & $\operatorname{Rp~2,857,427,000}$ & $\operatorname{Rp~192,419,700}$ \\
\hline Margin Kontribusi & $\operatorname{Rp~2,833,357,000}$ & $\operatorname{Rp~} 1,102,573,000$ & $\operatorname{Rp~95,580,300~}$ \\
\hline Beban Tetap & $\operatorname{Rp~245,182,000}$ & $\operatorname{Rp~182,536,250}$ & $\operatorname{Rp~38,770,000}$ \\
\hline Laba Neto Operasi & $\operatorname{Rp~2,588,175,000}$ & $\operatorname{Rp~920,036,750}$ & $\operatorname{Rp~56,810,300}$ \\
\hline Tingkat Laverage Operasi & $\mathbf{1 . 0 9}$ & $\mathbf{1 . 2 0}$ & $\mathbf{1 . 6 8}$ \\
\hline
\end{tabular}

Sumber : Data diolah 2018

Besarnya tingkat laverage operasi pada UMKM Gunung Seulawah sebesar 1,09, UMKM Bungong Jaroe sebesar 1,20 dan UMKM Rencong Aceh 1,68, sehingga semakin besar tingkat OL maka akan semakin banyak perubahan dalam aktivitas penjualan yang dapat mempengaruhi laba perusahaan. Dalam nilai tingkat laverage operasi $1,09 \%$ pada UMKM Gunung Seulawah artinya apabila perusahaan mengalami peningkatan penjualan sebesar $1 \%$ maka perusahaan berpeluang mendapatkan laba sebesar 10,9\%, pada UMKM Bungong Jaroe tingkat OL $1,20 \%$ memiliki arti bahwa setiap peningkatan penjualan sebesar $1 \%$ maka perusahaan berpeluang mendapat laba sebesar 12\%, dan yang terakhir UMKM Rencong Aceh yang memiliki nilai tingkat laverage

1) UMKM Gunung Seulawah operasi sebesar $1,68 \%$ maka menunjukan setiap kenaikan penjualan $1 \%$ maka perusahaan memiliki peluang mendapat laba sebesar $16,8 \%$.

\section{Perencanan Laba}

Perencanaan yang dibuat di dalam unit usaha dibuat berdasarkan perbanding antara perbandingan penjualan actual tahun sebelumnya. Pada tahun 2017 UMKM dendeng diharapkan memiliki kenaikan penjualan yang pasti akan berdampak pada kenaikan laba, pada tahun 2018 diharapkan setiap UMKM memiliki kenaikan laba 15\% dari laba tahun 2017. Berikut merupakan target laba yang dihitung untuk tahun 2018 diacu dari laba yang didapat tahun 2017: 
Tabel 4.21

Laporan Laba Rugi Sederhana

UMKM Dendeng Gunung Seulawah

\begin{tabular}{|c|l|l|l|}
\hline Penjualan & & & Rp 10,080,000,000 \\
\hline Bb & & Rp 7,011,640,000 & \\
\hline Tkl & & Rp 162,000,000 & \\
\hline Biaya Overhead & & & \\
\hline Kotak & Rp210,000,000 & & \\
\hline Plastic & Rp 6,160,000 & & \\
\hline Listrik & Rp10,293,000 & & \\
\hline Pdam & Rp 4,140,000 & & \\
\hline Biaya Angkut & Rp 4,410,000 & & \\
\hline Perawatan Mesin & Rp1,800,000 & & \\
\hline Penyusutan Mesin & Rp22,432,000 & & \\
\hline Total Biaya Overhead & & Rp 259,235,000 & \\
\hline Beban Non Produksi & & & Rp 7,491,825,000 \\
\hline Beban Lainnya & & & Rp 2,588,175,000 \\
\hline Total Biaya & & & \\
\hline Laba Operasi & & & \\
\hline
\end{tabular}

Sumber : data diolah 2018

Target laba $15 \%$ = laba tahun sebelumnya + (persen kenaikan $*$ laba tahun sebelumnya)

$=\mathrm{Rp} 2.588 .175 .000+(15 \% * \mathrm{Rp}$

2.588.175.000)

$=$ Rp. 2.976 .401 .250

Sehingga laba yang diharapkan pada tahun 2018 oleh UMKM Gunung Seulawah sebesesar Rp. 2.976.798.000,- dengan target laba tersebut maka penjualan yang harus dicapai dapat dihitung sebagai berikut:

2) UMKM Bungong Jaroe
Penjualan $=($ biaya tetap + laba yang diharapkan $) /($ harga jual per unit + biaya variabel per unit)

Penjualan $=(\operatorname{Rp} 245.182 .000+$ Rp. 2.976.401.250 $) /$ Rp 412.539

Penjualan $=47,755$

Sehingga dalam mencapai laba yang direncanakan pada tahun 2018 maka UMKM Gunung seulawah harus mampu menjual produknya 47,755 unit.

Tabel 4.22

Laporan Laba Rugi Sederhana

UMKM Dendeng Bungong Jaroe

\begin{tabular}{|l|l|l|l|}
\hline Penjualan & & & Rp3,960,000,000 \\
\hline Bb & & Rp2,801,018,000 & \\
\hline Tkl & & Rp 109,200,000 & \\
\hline Biaya overhead & & & \\
\hline$\quad$ Kotak & Rp 49,500,000 & & \\
\hline Plastic & Rp 1,530,000 & & \\
\hline$\quad$ Listrik & Rp 2,474,000 & & \\
\hline
\end{tabular}




\begin{tabular}{|c|l|l|l|}
\hline Biaya Angkut & Rp 2,905,000 & & \\
\hline Perawatan Mesin & Rp 700,000 & & \\
\hline Penyusutan Mesin & Rp 6,086,250 & & \\
\hline btkl & Rp 30,000,000 & & \\
\hline Total biaya overhead & & Rp 93,195,250 & \\
\hline Beban Non Produksi & & & \\
\hline Beban Lainnya & & Rp 36,550,000 & \\
\hline Total Biaya & & & Rp 3,039,963,250 \\
\hline Laba Operasi & & & Rp 920,036,750 \\
\hline
\end{tabular}

Sumber : data diolah 2018

Target laba $15 \%$ = laba tahun sebelumnya + (persen kenaikan * laba tahun sebelumnya)

$=\quad$ Rp. 920,036,750+ (Rp. $920,036,750 * 15 \%)$

$=$ Rp. 1,058,042,263, -

Sehingga laba yang diharapkan pada tahun 2018 oleh UMKM Bungong Jaroe sebesar Rp. 1,058,042,263,- dengan target laba tersebut mampu menambah penjualan produknya dapat dihitung sebagai berikut:

3) UMKM Rencong Aceh
Penjualan $=($ biaya tetap + laba yang diharapkan $) /($ harga jual per unit + biaya variabel per unit)

Penjualan $=(\operatorname{Rp} 182.536 .250+1.058 .042 .263) / R p$ 378,478

Penjualan $2018=20,253$ unit

Sehingga dalam mencapai laba yang direncanakan pada tahun 2018 maka UMKM Bungong Jaroe harus mampu menjual produknya sebanyak 20,253 unit pada tahun tersebut

Tabel 4.23

Laporan Laba Rugi Sederhana

UMKM Dendeng Rencong Aceh

\begin{tabular}{|c|c|c|c|}
\hline Penjualan & & & Rp288,000,000 \\
\hline $\mathrm{Bb}$ & & Rp185,715,700 & \\
\hline Tkl & & Rp32,400,000 & \\
\hline \multicolumn{4}{|l|}{ Biaya overhead } \\
\hline Kotak & $\mathrm{Rp} 4,800,000$ & & \\
\hline Plastic & Rp307,000 & & \\
\hline Listrik & Rp337,000 & & \\
\hline Biaya Angkut & Rp1,260,000 & & \\
\hline Perawatan Mesin & R p255,000 & & \\
\hline Penyusutan Mesin & Rp4,995,000 & & \\
\hline Total biaya overhead & & Rp11,954,000 & \\
\hline \multicolumn{4}{|l|}{ Beban Non Produksi } \\
\hline Beban Lainnya & & $\mathrm{Rp} 1,120,000$ & \\
\hline Total Biaya & & & Rp231,189,700 \\
\hline Laba Operasi & & & Rp56,810,300 \\
\hline
\end{tabular}

Sumber : data diolah 2018 
Target laba $15 \%$ = laba tahun sebelumnya + (persen kenaikan * laba tahun sebelumnya)

$$
=\text { Rp. Rp56,810,300 + }
$$$$
\operatorname{Rp} 56,810,300 * 15 \%)
$$$$
=\text { Rp. } 65,331,845,-
$$

Sehingga laba yang diharapkan pada tahun 2018 oleh UMKM Rencong Aceh sebesar Rp. 65.331.845,-dengan target laba tersebut maka penjualan yang harus dicapai dapat dihitung sebagai berikut:

Target laba $15 \%$ = laba tahun sebelumnya + (persen kenaikan * laba tahun sebelumnya)

Penjualan $=(38,770,000+\mathrm{Rp} \cdot 65,331,845) / \mathrm{Rp}$ 400,350

Penjualan $2018=1,307$ Unit

Sehingga dalam mencapai laba yang direncanakan pada tahun 2018 maka UMKM Rencong Aceh harus mampu menjual produknya sebanyak 1307 unit pada tahun tersebut.

\section{Kesimpulan, Keterbatasan Penelitian, dan saran \\ Kesimpulan}

Dari keseluruhan data yang terdiri dari harga jual, volume penjualan seta biaya-biaya ( biaya tetap dan biaya variabel) pada 3 UMKM (Usaha Mikro Kecil Menengah) yang bergerak pada bidang industri makanan berupa dendeng sapi yang berada di Kota Banda Aceh, maka data yang telah di dapat dalam penelitian telah diolah serta dianalisa dengan metodemetode yang digunakan dalam melakukan analisis CPV, dapat diambil kesimpulan sebagai berikut :

1) UMKM dendeng Gunung Seulawah memiliki total penjualan pada tahun 2017 sebesar Rp.10.080.000.000,- $\quad$ sebelum dilakukan perhitungan dengan CPV total biaya sebesar Rp 7,404,233,000 dan setelah dilakukan klasifikasi biaya maka jumlah biaya variabelnya sebesar $\mathrm{Rp}$ 7,246,643,000,- dan biaya tetapnya sebesar $R p$ 245,182,000,- sedangkan UMKM Bungong Jaroe memiliki total penjualan pada tahun 2017 sebesar Rp.3.960.000.000,- sebelum dilakukan perhitungan dengan CPV total biaya sebesar $\mathrm{Rp}$ 2,998,222,000 dan selanjutya biaya-biaya yang ada di di UMKM ini juga dilakukan pengklasifikasian mulai dari biaya variabel sebesar Rp.2.857.427.000,- dan biaya tetap sebesar Rp.82.536.250,00,- dan yang terakhir UMKM Rencong Aceh yang juga memiliki total biaya sebelum dilakukan analisis CPV berjumlah Rp 223,559,700 setelah biayanya di klasifikasikan maka total biaya variabelnya sebesar Rp. 192,419,700,- dan biaya tetapnya sebesar Rp.38.770.000,-.

2) Setelah data penjualan dan biaya-biaya diketahui maka laba masing-masing UMKM juga dapat diketahui, diperkirakan Gunung Seulawah memiliki total laba di tahun 2017 sebelum menggunakan CPV sebesar sebesar Rp 2,675,767,000 dengan CM sebesar Rp 2,675,767,000 dan per unitnya sebesar Rp 67,566 dan rasio CM sebesar 28\% dan setelah dilakukan perhitungan menggunakan alat-alat CPV jumlah labanya berubah menjadi 2.588 .175 .000 ,- dengan nilai CM sebesar Rp. 2.833.357.000,- dan CM per unitnya sebesar Rp. 172.539,- dengan rasio CM sebesar 28\%. UMKM Bungong Jaroe mencapai laba di tahun $2017 \mathrm{Rp} 961,778,000$ dengan jumlah CM sebesar Rp. 1,100,978,000 dan CM perunitnya Rp. 61,165 serta rasio $\mathrm{CM}$ berjumlah $28 \%$ setelah ddilakukan perhitungan laba menggunakan CPV nilai labanya berubah menjadi Rp. 920.036.750,.- memiliki nilai CM sebesar Rp. 1.102.573.000,- dan per unitnya Rp. 158.746,serta nilai rasio CM sebesar 28\%. UMKM Rencong Aceh mencapai laba di tahun 2017 sebesar $\mathrm{Rp}$ 64,440,300 dengan nilai CM sebesar Rp. $96,840,300$ per unitnya Rp. 80,700 dan rasio CM sebesar 34\% namun jumlah laba nya berubah setelah dihitung menggunkan analisi CPV menjadi Rp. 56.810.300,- dengan nilai CM Rp. 95.580.300, - per unitnya Rp. 79.650,25,- dan nilai rasio $C M$ sebesar $33,3 \%$. Sehingga menunjukan bahwa total laba setelah menggunakan CPV lebih dibanding laba yang diperkirakan oleh pelaku usaha yang tidak menggunakan analisis CPV, terjadinya penurunan laba karena terdapat biaya-biaya yang belum diakui dalam perhitungan mencari jumlah biayanya dan total labanya. Nilai rasio $C M$ menunjukan bahwa setiap kenaikan unit penjualan maka laba juga meningkat sebesar nilai 
rasio $C M$ dengan asumsi tidak ada perubahan biaya.

3) Masing-masing UMKM memiliki nilai penjualan dalam keadaan BEP pada tahun 2017 sebagai berikut, sebelum menggunakan CPV penjualan dalam keadaan BEP Gunung Seulawah memiliki nilai sebesar Rp. 575,438,364 dan per unitnya sebesar 2,398 unit, setelah BEP dihitung menggunakan $\mathrm{CPV}$ maka nilai penjualan dalam keadaan BEP menjadi Rp 872.263.735,- dengan total unit sebanyak 3,634 unit dengan penjualan aktual sebesar Rp.10.080.000.000,- total unit terjual 42.000. UMKM Bungong Jaroe dalam perhitungan penjualan dalam keadaan BEP sebelum menggunakan CPV nilainya sebesar Rp $500,674,855$ dan per jumlah unitny adalah 2,276 unit, setelah dilakukan perhitungan menggunakan ala-alat CPV maka nilai penjualan dalam keadaan BEP sebesar Rp. 655.596.999,- dan BEP unitnya 2.980 unit, sedangkan penjualan yang aktual sebesar Rp.3.960.000.000,- dengan unit terjual 18.000 unit. UMKM Rencong Aceh memiliki penjualan dalam keadaan BEP sebesar Rp 96,356,579 dengan total uni sebanyak 401 unit sebelum dilakukan perhitungan menggunakan $\mathrm{CPV}$, namun setelah menggunakan $\mathrm{CPV}$ nilai penjualan dalam keadaan CPV berubar menjadi Rp. 116,820,726 dan BEP unit 487 unit, dengan penjualan aktualnya sebesar Rp.288.000.000,dengan total unit terjualnya sebanyak 1.200 unit. Dari data yang didapat menunjukan UMKM dendeng sapi yang diteliti oleh peneliti dapat mencapai BEP, sudah pasti karena telah mencapai BEP unit usaha nya mencapai keuntungan di tahun 2017. Penjualan dalam BEP juga memiliki nilai lebih rendah sebelum menggunakan CPV baiik itu dalam jumlah rupiah atau pun unit.

4) Margin Of Safety dari UMKM Gunung Seulawah sebelum menggunakan CPV sebesar 94\% yang berarti batas maksimal penurunan penjualan untuk periode yang akan mendatang tidak boleh kurang dari 39,602 unit atau Rp 9,504,561,636, setelah dihitung menggunakan CPV maka persentase MOS nya sebesar $91 \%$ dengan batas maksimal penurunan tidak boleh kurang dari 38.366 unit atau sebesar Rp. 9.207.736.265,- , jika perusahaan memiliki penurunan penjualan dari jumlah yang telah dihitung maka UMKM Gunung
Seulawah akan mengalami kerugian. Margin $O f$ Safety dari UMKM Bungong Jaroe sebelum menggunakan CPV memiliki batas penurunan penjualan sebesar $87 \%$ dengan jumlah 15,724 unit atau Rp. 3,459,325,145, dan setelah perhitungan menggunakan CPV maka batas penurunannya berubah menjadi $83 \%$ yang berarti batas maksimal penurunan penjualan untuk periode yang akan mendatang tidak boleh kurang dari 15.020 unit atau sebesar Rp. 3.304.403.000,-, jika perusahaan memiliki penurunan penjualan lebih dari yang diperhitungkan maka UMKM Bungong Jaroe akan mengalami kerugian. Margin Of Safety dari UMKM Rencong Aceh sebelum menggunakan CPV sebesar $67 \%$ dengan total batas penurunan penjualan unitnya sebesar 799 unit atau Rp. 191,643,421 dan setelah dihitung menggunakn CPV makan persentase batas penurunan penjualannya berubah menjadi 59\% yang berarti batas maksimal penurunan penjualan untuk periode yang akan mendatang tidak boleh kurang dari 713 unit atau sebesar Rp. 171.179.274,- , jika perusahaan memiliki penurunan penjualan lebih dari data yang telah dihitung maka UMKM Rencong Aceh akan mengalami kerugian. Total MOS menjadi lebih kecil setelah menggunakan CPV dibandingkan perhitungan tanpa menggunakan CPV.

5) Tingkat leverage operasi merupakan sebuah ukuran pada perusahaan pada tingkat penjualan tertentu, maka setiap perubahan penjualan akan mempengaruhi jumlah laba. Nilai Tingkat Laverage Operasi UMKM Gunung Seulawah sebelum menggunakan CPV sebesar 1.06 dimana setiap kenaikan $1 \%$ pada pendapatan penjualan maka laba juga akan naik sebesar $106 \%$, namun setelah menggunakan CPV berubah menjadi 1,09 yang menunjukan atau 109\% yang menunjukan setiap $1 \%$ kenaikan pendapatan penjualan akan mengakibatkan kenaikan 109\% kenaikan pada laba. Nilai Tingkat Laverage Operasi UMKM Bungong Jaroe sebelum menggunakan CPV sebesar 1.14 yang menunjukan setiap kenaikan $1 \%$ laba berakibat pada kenaikan laba sebesar $114 \%$, setelah menggunakan perhitungan CPV nilai tingkat laveragenya menjadi 1,20 yang menunjukan atau $112 \%$ yang menunjukan setiap $1 \%$ kenaikan pendapatan penjualan akan 
mengakibatkan kenaikan $120 \%$ kenaikan pada laba. Nilai Tingkat Laverage Operasi UMKM Rencong Aceh sebelum menggunakan CPV sebesar 1.50 atau setiap kenaikan $1 \%$ total pejualan makan total laba juga mengalami kenaikan sebsar $150 \%$, msetelah menggunakan CPV nilai Laverage Operasinya menjadi 1,68 yang menunjukan atau $168 \%$ yang menunjukan setiap $1 \%$ kenaikan pendapatan penjualan akan mengakibatkan kenaikan $168 \%$ kenaikan pada laba.

6) Dari data yang telah dihitung menggunakan alat yang digunakan pada analisi cost volume provit maka target laba yang direncanakan setiap UMKM diharapkan mengalami peninkatan sebesar $15 \%$ dari tahun sebelumnya. UMKM Gunung Seulawah target laba Rp. 2.976.401.250,yang bisa dicapai dengan total penjualan sebanyak 47.755 unit dengan asumsi tidak ada perubahan biaya. UMKM Bungong Jaroe target laba Rp. 1.058.042.263,.- yang bisa dicapai dengan total penjualan sebanyak 20.253 dengan asumsi tidak ada perubahan biaya. UMKM Rencong Aceh target laba Rp. 65.331.845,-yang bisa dicapai dengan total penjualan sebanyak 1.307 unit dengan asumsi tidak ada perubahan biaya.

\section{Keterbatasan Penelitian}

Terdapat bebrapa keterbatan dalam penulisan penelitian ini, yaitu:

1) Penelitian ini hanya menggunakan 3 sampel unit usaha di Kota Banda Aceh yang hanya meneliti 1 (satu) buah produk yaitu dendeng daging sapi dari setiap unit usaha dendeng yang ada, sehingga hasilnya tidak dapat digeneralisasi secara umum.

2) Akurasi data yang diperoleh dari penelitian ini mungkin tidak $100 \%$ akurat, karena keterbatasan UMKM yang tidak melakukan pencatatan secara lengkap dan akurat dalam sistem penjualannya baik pada penerimaan maupun pada pembiayaan.

3) Dalam penelitian ini tidak mencoba menganalisis dengan menggunakan dasar penyusunan anggaran laba masa depan yang memperhitungkan yang memperhitungkan ketidakpastian.

\section{Saran}

Dari penelitian yang telah dilakukan dan hasil yang diperoleh, maka peneliti ingin memberikan beberapa saran sebagai berikut:

1) Para pelaku usaha sebaiknya membuat laporan keuangan untuk setiap unit usaha yang dijalankan, meskipun laporan yang dibuat berupa laporan keuangan sederhana. Laporan keuangan sebab dapat memberikan gambaran yang detail menggunakan kondisi keuangan perusahaan.

2) Perusahaan diharapkan menggunakan hasil identifikasi serta pengklasifikasian biaya seperti biaya variabel dan biaya tetap agar dapat mendapatkan hasil perencanaan laba yang optimal yang digunakan untuk waktu yang akan datang.

3) Setiap unit usaha sebaiknya menggunakan analisis CPV serta melakukan perencanaan laba yang digunakan sebagai alat pengawasan dan pengendalian operasional perusahaan dengan menggunakan alat CVP seperti BEP, MOS, CM, dan OL.

4) Perusahaan sebaiknya melakukan perencanaan laba yang harus dicapai untuk setiap tahunnya, dengan menggunakan alat-alat seperti BEP, MOS, CM, Operating Laverage.

5) Setiap unit usaha dendeng sapi diusahakan agar tetap melewati BEP setiap tahunnya agar tetap mendapatkan laba.

6) Untuk UMKM dendeng khususnya unit usah Rencong Aceh sebaiknya mengikuti jejak-jejak UMKM Gunung seulawah dan Bungong Jaroe untuk mengambil bahan baku di tempat yang sama agar harga dagingnya juga lebih murah sehingga memperkecil biaya yang dikeluarkan yang sudah pasti mengurangi beban perusahaan agar dapat menaikkan atau memeperbesar mendapatkan laba yang optimal.

7) Untuk para peneliti selanjutnya yang juga tertarik mengenai analisis CVP yang digunakan sebagai alat merencanakan laba, diharapkan agar dapat memperluas cakupan ruang lingkup penelitian.

8) Pemerintah daerah Kota Banda Aceh juga sebaiknya memiliki peran yang aktif terhadap UMKM-UMKM, memberikan perhatian lebih serta pembinaan rutin kepada setiap pelaku usaha mengenai cara peneglolaan usaha yang baik dan benar seperti pembuatan pembukuan, penentuan 
harga dengan analisis-analisis perhitungan harga pokok penjualan, dll.

9) Setiap unit usaha sebaiknya menggunakan analisis CPV serta melakukan perencanaan laba yang digunakan sebagai alat pengawasan dan pengendalian operasional perusahaan dengan menggunakan alat CVP seperti BEP, MOS, CM, dan OL.

10) Perusahaan sebaiknya melakukan perencanaan laba yang harus dicapai untuk setiap tahunnya, dengan menggunakan alat-alat seperti BEP, MOS, CM, Operating Laverage.

11) Setiap unit usaha dendeng sapi diusahakan agar tetap melewati BEP setiap tahunnya agar tetap mendapatkan laba.

12) Untuk UMKM dendeng khususnya unit usah Rencong Aceh sebaiknya mengikuti jejakjejak UMKM Gunung seulawah dan Bungong Jaroe untuk mengambil bahan baku di tempat yang sama agar harga dagingnya juga lebih murah sehingga memperkecil biaya yang dikeluarkan yang sudah pasti mengurangi beban perusahaan agar dapat menaikkan atau memeperbesar mendapatkan laba yang optimal.

13) Untuk para peneliti selanjutnya yang juga tertarik mengenai analisis CVP yang digunakan sebagai alat merencanakan laba , diharapkan agar dapat memperluas cakupan ruang lingkup penelitian.

14) Pemerintah daerah Kota Banda Aceh juga sebaiknya memiliki peran yang aktif terhadap UMKM-UMKM, memberikan perhatian lebih serta pembinaan rutin kepada setiap pelaku usaha mengenai cara peneglolaan usaha yang baik dan benar seperti pembuatan pembukuan, penentuan harga dengan analisis-analisis perhitungan harga pokok penjualan, dll.

\section{Daftar Pustaka}

Abdullahi, S. R., Sulaimon, B. A., Mukhtar, I. S., \& Musa, M. H. (2017). Cost-Volume-Profit Analysis As A Management Tool For Decision Making In Small Business Enterprise Within Bayero University , Kano. Iosr Journal of Business And Management (Iosr-Jbm), 19(2), 40-45. Https://Doi.Org/10.9790/487X1902014045

Akmese, H., Buyuksalvarci, A., \& Akmese, K. (2016).
The Use Of Cost-Volume-Profit Analysis In Turkish Hotel Industry, 90-97.

Assa, R. L. (2013). Analisis Cost-Volume-Profit (Cvp) Dalam Pengambilan Keputusan Perencanaan Laba Pada Pt. Tropica Cocoprima. Emba, 1(3), 591-601.

Blocher, Edward J., David E, S., \& Cokinns, G. (2011). Manajemen Biaya (5th Ed.). Jakarta: Salemba Empat.

Bps Kota Banda Aceh. (2017).

Bugin, B. (2007). Penelitian Kualitatif (2nd Ed.). Jakarta: Perdana Media Group.

Carter, William K. (2011). Akuntansi Biaya (14th Ed.). Jakarta: Salemba Empat.

Coper, D. ., \& Emory, C. . (1996). Metodologi Penelitian Bisnis (Edisi Keli). Jakarta: Erlangga.

Dr. Ulber Silalahi, M. (2012). Metode Penelitian Sosial. (A. G. Sh, Ed.) (3rd Ed.).

Eldenburg, L. G., Brooks, A., Oliver, J., Vesty, G., \& Wolcott, S. (2011). Management Accounting. (L. John Wilet \& Sons Australia, Ed.) (2nd Ed). Nationaly Library Of Australia.

Etges, A. P. B. Da S., Calegar, R., Rhoden, M. I. Dos S., \& Cortimiglia, M. N. (2016). Using CostVolume-Profit To Analyse The Viability Of Implementing A New Distribution Center. Brazilian Journal Of Operations \& Production Management 13, 13, 44-50. Https://Doi.Org/10.14488/Bjopm.2016.V13.N1. A4

Garrison, R. H, Noreen, E. W., \& Brewer, P. C. (2014). Akuntansi Manajerial (114 Buku 1). Jakarta: Salemba Empat.

Punniyamoorthy Harahap, S. S. (2008). Analisis Kritis Atas Laporan Keuangan. Jakarta: Pt Raja Grafindo Persada.

Hilneedl

Hilton, Ronald W, \& Platt, D. E. (2011). Managrial Accounting: Creating Value In A Global Business Environment (Ninth Edit). 1221 Avenue Of The Amerias, Nw York: McgrawHill Irwin.

Iddrisu, A. (2016). Practical Application Of Analysis On Agro- Products: Evidence From Female Micro-Agro Distributors In The Tamale Metropolitan Area Of Ghana, 4(1), 1-17.

Iswara, Ulfah Setia, \& Susanti. (2017). Analisis Cost Volume Profit Sebagai Dasar Perencanaan Laba 
Yang Diharapkan (Studi Pada Perusahaan Kopi

Di Kabupaten Jember). Jurnal Riset Akuntansi Keuangan, 2, 67-76.

Kembi, L. D., Sondakh, J. J., \& Tirayoh, V. Z. (2014). Perencanaan Laba Berdasarkan Analisis Biaya, Volume, Laba Pada Pt. Multi Food Manado. Emba, 2(4), 354-362.

Koraag, J. F., \& Ilat, V. (2016). Analisis CostVolume-Profit Untuk Perencanaan Laba Pada Pabrik Tahu "Ibu Siti," 16(3), 803-812.

Kotler., P. (2004). Manajemen Pemasaran (1st Ed.). Jakarta: Pt Prenhallinda.

Machfoeds, M. (2000). Akuntansi Manajemen: Perencanaan Dan Pembuatan Keputusan Jangka Pendek (Edisi 5, B). Yogyakarta: Bpfe.

Mulansari, D., \& Ismawati, K. (2016). Analisis Perencanaan Laba Dengan Menggunakan Metode Cost-Volume-Profit (Cvp) Pada Pt. Indo Acidatama Tbk. Jurnal Penelitian Dan Kajian Ilmiah, 14(4), 7-15.

Mulyadi. (2001). Akuntansi Manajmen. Yogyakarta: Salemba Empat.

Murthosiyah, S., Theresia, M., \& Widyarti, H. (2015). Perencanaan Laba Menggunakan Analisis Biaya- Volume-Laba Pada Ukm Slamet Semarang Tahun 2014. Jabpi, 23(1), 39-49.

Navaneetha, B., Punitha, K., Joseph, R. M., Rashmi, S., \& Aishwariyaa, T. S. (2017). An Analysis Of Cost Volume Profit Of Nestlé Limited, 3(3), 66-68.

Needles, B. E., \& Crosson, S. V. (2011). Managrial Accounting. (R. Dewey, Ed.) (9th Editio). Asia: South-Western Cencage Learning.

Palawiten, A., \& Ilat, V. (2014). Analisis Cost Volume Profit Untuk Perencanaan Laba Pada Ud Gladys Bakery. Emba, 2(2), 1670-1681.

Punniyamoorthy, R. (2017). Examining Cost Volume Profit And Decision Tree Analysis of A Selected Company. World Wide Journal of Multidiscipl Inary Research And Development Wwjmrd, 3(9), 224-233.

Radiosunu. (2000). Manajemen Pemasaran: Suatu Pendekatan Analisis Perencanaan Dan Pengendalian. Jakarta: Erlangga.

Raiborn, C. A., \& Kinney, M. R. (2011). Cost Accounting Principles (8th Editio). MurthosiyaAsia: South-Western Cengage Learning.
Satriani, S., Marheni, \& Miranda, L. (2015). Analisis Cost-Volume-Profit Sebagai Alat Perencanaan Laba Jangka Pendek Pada Cv. Mentari Dempo Indah Pangkalpinang. Jiabk, 3(2), 28-42.

Sekaran, U., \& Bogie, R. (2013). Research Metodhs For Business:A Skill Building Approah 6th Edition (6th Ed.). New York: John Willey \& Sons Ltd.

Sihombing, S. B. (2013). Analisis Biaya-Volume-Laba Sebagai Alat Bantu Perencanaan Laba Pt. Emba, 1(3), 181-188.

Sugiyono, P. D. (2014). Metode Penelitian Kuantitatif Kualitatif Dan $R \& D$.

Utami, E. F. K., Dwiatmanto, \& Np, M. G. W. E. (2016). Analisis Cost Volume Profit Sebagai Perencanaan Penjualan Untuk Mencapai Laba Yang Diinginkan ( Studi Pada Pabrik Gula Tjoekir , Jombang-Jawa Timur ). Jab, 34(1), 181-188.

UUD RI Nomor 20 Tahun 2008. (N.D.).

Wild, John J, \& Shaw, K. W. (2012). Managerial Acounting. (S. Mattson, Ed.) (3rd Ed). United Stetes: Mcgraw-Hill Irwin.

Winarko, S. P., Astuti, P., \& Wijayanti, F. (2017). Analisis Biaya Volume Laba Sebagai Alat Bantu Perencanaan Laba Pada Perusahaan Pia Latief Kediri. Jurnal Akuntansi Dan Ekonomi Fe. Un Pgri Kediri, 2(2), 102-117.

Worotitjan, E. E., \& Manossoh, H. (2016). Analisis Cost-Volume-Profit Untuk Perencanaan Laba Pada Ud. Gunung Emas Manado. Emba, 4(1), 585-592.

www.depkop.go.id. (n.d.). www.diskop.acehprov.go.id. (n.d.). 